\title{
Targeted Deletion of the Kynurenine Aminotransferase II Gene Reveals a Critical Role of Endogenous Kynurenic Acid in the Regulation of Synaptic Transmission via $\alpha 7$ Nicotinic Receptors in the Hippocampus
}

\author{
Manickavasagon Alkondon, ${ }^{1 \star}$ Edna F. R. Pereira, ${ }^{1 \star}$ Ping Yu,${ }^{2 *}$ Emerson Z. Arruda, ${ }^{1,3 *}$ Luis E. F. Almeida, ${ }^{1}$ \\ Paolo Guidetti, ${ }^{4}$ William P. Fawcett, ${ }^{1}$ Michael T. Sapko, ${ }^{4}$ William R. Randall, ${ }^{1}$ Robert Schwarcz, ${ }^{1,4}$ Danilo A. Tagle, ${ }^{2}$ and \\ Edson X. Albuquerque ${ }^{1,3}$ \\ ${ }^{1}$ Department of Pharmacology and Experimental Therapeutics, University of Maryland School of Medicine, Baltimore, Maryland 21201, ${ }^{2}$ Genetics and \\ Molecular Biology Branch, National Human Genome Research Institute, National Institutes of Health, Bethesda, Maryland 20892, ${ }^{3}$ Departamento de \\ Farmacologia Básica e Clínica, Instituto de Ciências Biomédicas, Centro de Ciências da Saúde, Universidade Federal do Rio de Janeiro, Rio de Janeiro, RJ \\ 21944, Brazil, and ${ }^{4}$ Maryland Psychiatric Research Center, University of Maryland School of Medicine, Baltimore, Maryland 21228
}

It has been postulated that endogenous kynurenic acid (KYNA) modulates $\alpha 7^{\star}$ nicotinic acetylcholine receptor (nAChR) and NMDA receptor activities in the brain. ${ }^{a}$ To test this hypothesis, $\alpha 7^{\star} \mathrm{nAChR}$ and NMDA receptor functions were studied in mice with a targeted null mutation in the gene encoding kynurenine aminotransferase II ( $m$ Kat- $2^{-/-}$mice), an enzyme responsible for brain KYNA synthesis. At 21 postnatal days, $m \mathrm{Kat}_{-2^{-/}}$mice had lower hippocampal KYNA levels and higher spontaneous locomotor activity than wild-type (WT) mice. At this age, $\alpha 7^{\star}$ nAChR activity induced by exogenous application of agonists to CA1 stratum radiatum interneurons was $\sim 65 \%$ higher in $m \mathrm{Kat}_{-2^{-/}}$than WT mice. Binding studies indicated that the enhanced receptor activity may not have resulted from an increase in $\alpha 7^{\star} \mathrm{nAChR}$ number. In 21-d-old $m K a t-2^{-/-}$mice, endogenous $\alpha 7^{\star} \mathrm{nAChR}$ activity in the hippocampus was also increased, leading to an enhancement of GABAergic activity impinging onto CA1 pyramidal neurons that could be reduced significantly by acute exposure to KYNA $(100 \mathrm{nM})$. The activities of $\mathrm{GABA}_{\mathrm{A}}$ and NMDA receptors in the interneurons and of $\alpha 3 \beta 4^{*}$ nAChRs regulating glutamate release onto these neurons were comparable between $m K a t-2^{-1-}$ and WT mice. By $60 \mathrm{~d}$ of age, KYNA levels and GABAergic transmission in the hippocampus and locomotor activity were similar between $m K a t-2^{-/-}$and WT mice. Our findings that $\alpha 7^{\star}$ nAChRs are major targets for KYNA in the brain may provide insights into the pathophysiology of schizophrenia and Alzheimer's disease, disorders in which brain KYNA levels are increased and $\alpha 7^{\star}$ nAChR functions are impaired.

Key words: nicotinic receptors; kynurenic acid; NMDA receptors; GABA; hippocampus; mice

\section{Introduction}

Neuronal nicotinic acetylcholine receptors (nAChRs) are acetylcholine-gated channels that are essential for development and plasticity of the mammalian CNS (McGehee, 2002). Of the several neuronal nAChR subtypes identified to date, $\alpha 7^{\star}, \alpha 4 \beta 2^{\star}$, and $\alpha 3 \beta 4^{\star}$ nAChRs are present in the hippocampus (Albuquer-

Received Dec. 21, 2003; revised March 29, 2004; accepted March 29, 2004.

This work was supported in part by United States Public Health Service Grants NS25296 and NS41671. We are indebted to Mabel Zelle for her expert technical assistance and Bhagavathy Alkondon for her technical support.

*M.A., E.F.R.P., P.Y., and E.Z.A. contributed equally to this work.

Correspondence should be addressed to Dr. Edson X. Albuquerque, Department of Pharmacology and Experimen-

tal Therapeutics, University of Maryland School of Medicine, 655 West Baltimore Street, Baltimore, MD 21201. E-mail: ealbuque@umaryland.edu.

D. A. Tagle's present address: Neurogenetics, National Institute of Neurological Disorders and Stroke, National Institutes of Health, 6001 Executive Boulevard, Bethesda, MD 20892.

P. Yu's present address: Structure Biophysics Laboratory, National Cancer Institute, National Institutes of Health, Frederick, MD 21702.

DOI:10.1523/JNEUROSCI.5631-03.2004

Copyright $\odot 2004$ Society for Neuroscience $\quad 0270-6474 / 04 / 244635-14 \$ 15.00 / 0$ que et al., 1997). ${ }^{a}$ For several reasons, $\alpha 7^{\star}$ nAChRs are unique among nAChRs: (1) they have high $\mathrm{Ca}^{2+}$ permeability, short open time, and fast rate of ${ }^{1}$ desensitization, (2) they can be blocked by nanomolar concentrations of methyllycaconitine (MLA) or $\alpha$-bungarotoxin ( $\alpha$-BGT), and (3) they can be fully activated by the ACh metabolite choline (Pereira et al., 2002). In addition, $\alpha 7^{*} \mathrm{nAChRs}$ and chimeric $\alpha 7 / 5-\mathrm{HT}_{3}$ receptors in HEK293 cells are highly sensitive to blockade by kynurenic acid (KYNA) $\left(\mathrm{IC}_{50}\right.$ of $\sim 7 \mu \mathrm{M}$ ), a major brain metabolite of the kynurenine pathway of tryptophan degradation (Hilmas et al., 2001; Pereira et al., 2002).

The well established neuroprotective and anticonvulsant properties of KYNA have been traditionally attributed to its action as a competitive antagonist of glycine at NMDA receptors (Stone, 1993, 2001; Schwarcz and Pellicciari, 2002). In the nom-

${ }^{a}$ According to the current status of the nomenclature for nAChRs and their subunits (Lukas et al., 1999), the asterisk next to $\mathrm{nAChR}$ subunits throughout text is meant to indicate that the exact receptor subunit composition is not known. 
inal absence of glycine and in the presence of glycine concentrations similar to those found in the extracellular compartment of the brain (Kennedy et al., 2002), KYNA blocks NMDA receptors with $\mathrm{IC}_{50}$ values of $\sim 15$ and $230 \mu \mathrm{M}$, respectively (Hilmas et al., 2001). Considering that, under physiological conditions, brain KYNA concentrations range from low nanomolar to low micromolar (Moroni et al., 1988; Turski et al., 1988), it is unclear whether sufficient KYNA is present to regulate NMDA receptor activity in vivo (Scharfman et al., 1999; Urenjak and Obrenovitch, 2000).

Brain KYNA is synthesized primarily in astrocytes as a result of the irreversible transamination of L-kynurenine. In the adult rat and the human brain, $>70 \%$ of this synthesis is catalyzed by kynurenine aminotransferase II (KAT II) ( $\mathrm{L}-\alpha$-aminoadipate aminotransferease; E.C. 2.6.1.39); the remainder is catalyzed by KAT I (Guidetti et al., 1997; Kiss et al., 2003). Therefore, the actions of endogenous KYNA in the brain could be elucidated by in vivo manipulations of KAT II activity. The lack of selective KAT II inhibitors, however, and the characterization of the mouse Kat-2 gene led to the development of a KAT II-deficient mouse by targeted deletion (Yu et al., 1999a,b).

The present study uses $m \mathrm{Kat}-2^{-/-}$mice to test the hypothesis that $\alpha 7^{\star}$ nAChRs mediate the actions of endogenous KYNA in the brain. Results presented herein reveal that, at $21 \mathrm{~d}$ of age, $m$ Kat $-2^{-/-}$mice had lower hippocampal KYNA levels and higher locomotor activity than wild-type (WT) mice. At this age, $\alpha 7^{\star}$ $\mathrm{nAChR}$ activity in CA1 stratum radiatum (SR) interneurons and GABAergic synaptic activity impinging onto CA1 pyramidal neurons were also higher in $m K a t-2^{-/-}$than in WT mice. In contrast, NMDA receptor activity in the hippocampus of 21-d-old mutant and WT mice did not differ significantly. Furthermore, hippocampal levels of KYNA in WT and $m \mathrm{Kat}-2^{-/-}$mice became similar by $60 \mathrm{~d}$ of age, as did GABAergic synaptic activity impinging onto CA1 pyramidal neurons. Thus, in the hippocampus, KYNA is an endogenous modulator of the $\alpha 7^{\star}$ nAChR activity.

Parts of this work have been published previously in abstract form (Alkondon et al., 2003b).

\section{Materials and Methods}

\section{Genotyping mice nullizygous for mKat-2 (129SvEv)}

The mouse KAT II sequence and genomic organization were determined from BAC clones made from a 129/SVJ genomic library (Yu et al., $1999 \mathrm{a}, \mathrm{b})$. Mice with targeted deletion of the $m K a t-2$ gene were made at the National Institutes of Health under the Institutional Animal Care and Use Committee-approved animal protocol G-99-3 (Yu et al., 1999a). The animals were maintained in a 129SvEv background strain (Taconic, Germantown, NY). Two pairs of primers (see Fig. $1 A$ ) were used for screening and genotyping the mice: P1 (5'-ACA TGC TCG GGT TTG GAG AT- $\left.3^{\prime}\right)$ and P3 (5'-AAG CTT TGG AAC TCA GTG GG-3'), and P2 (5'-GTG GAT GTG GAA ATG TGT GTG GG-3') and P4 (5' -GAG ACA GAC ACC TTG ATA CT-3'). Genotypes were verified by PCR analysis under the following conditions. The reaction contained $50 \mathrm{ng}$ of mouse tail DNA, in MasterAmp buffer (Epicentere Technologies, Madison, WI), with 5 pmol of each primer and $0.2 \mathrm{U}$ of TaqDNA polymerase (Roche, Indianapolis, IN). Thermocycling parameters were as follows: 2 min at $94^{\circ} \mathrm{C}$, followed by 25 cycles of $40 \mathrm{sec}$ at $94^{\circ} \mathrm{C}, 40 \mathrm{sec}$ at $58^{\circ} \mathrm{C}$, and 1 $\min$ at $72^{\circ} \mathrm{C}$. Once $m \mathrm{Kat}-2^{-1-}$ mice were successfully generated, homozygous breeding pairs were established. Separate 129SvEvTac mice were bred to form a homozygous WT line. To minimize the risk of genetic drift in either homozygous line, $m \mathrm{Kat}_{-} 2^{-/-}$mice were paired with WT $129 \mathrm{SvEvTac}$ mice after every fourth generation. $m$ Kat $-2^{-1-}$ and WT mice from these pairings served as the breeders for subsequent generations. Mice were maintained in an Association for Assessment and Accreditation of Laboratory Animal Care-approved animal facility on a $12 \mathrm{hr}$ light/dark cycle, with food and water available ad libitum. Animal care and handling were done strictly in accordance with the guidelines set forth by the Animal Care and Use Committee of the University of Maryland, Baltimore and National Institutes of Health.

\section{Northern blots}

Total RNA from kidneys of 2-month-old WT and $m$ Kat- $2^{-/-}$mice were extracted using the Trizol reagent according to the protocol of the manufacturer (Invitrogen, Gaithersburg, MD). Total RNA of each $(10 \mu \mathrm{g})$ was subjected to electrophoresis on a $0.8 \%$ agarose gel and transferred to nitrocellulose membrane. The membrane was probed with $\left[\alpha-{ }^{32} \mathrm{P}\right]-$ labeled full-length $m$ Kat-2 cDNA in preHYB/HYB buffer (Quality Biological, Gaithersburg, MD), washed at high-stringency conditions with $0.2 \times$ SSC, and subjected to autoradiography at $-70^{\circ} \mathrm{C}$.

\section{Immunotitration of KAT II activity in mouse \\ hippocampal extracts}

Male mice were anesthetized in a $\mathrm{CO}_{2}$ atmosphere and killed by decapitation. Their hippocampi were rapidly removed and placed on ice. The tissues were suspended $(1: 20, \mathrm{w} / \mathrm{v})$ in distilled water and sonicated. The homogenate was then centrifuged $(10,000 \times g)$, and the supernatants were dialyzed overnight at $4^{\circ} \mathrm{C}$ against 41 of $5 \mathrm{~mm}$ Tris acetate buffer, $\mathrm{pH}$ 8.0 , containing pyridoxal-5-phosphate $(50 \mu \mathrm{M})$ and 2-mercaptoethanol $(10 \mathrm{~mm})$. KAT II was immunoprecipitated using a polyclonal rabbit antihuman KAT II antibody (Okuno et al., 1993; Yu et al., 1999b). To this end, either $1 \mu \mathrm{l}$ of antibody or $1 \mu \mathrm{l}$ of water was mixed with $100 \mu \mathrm{l}$ of the dialyzed tissue supernatant and incubated at $25^{\circ} \mathrm{C}$ for $1 \mathrm{hr}$. One milligram of insoluble protein $\mathrm{A}$, dissolved in $10 \mu \mathrm{l}$ of water, was then added, and the mixture was vigorously stirred and incubated at $25^{\circ} \mathrm{C}$ for $1 \mathrm{hr}$. After centrifugation $(12,000 \times g, 10 \mathrm{~min})$, KAT activity was measured in a total volume of $200 \mu \mathrm{l}$, containing $80 \mu \mathrm{l}$ of supernatant fluid, $150 \mathrm{~mm}$ Tris-acetate buffer, $\mathrm{pH} 7.4,2 \mu \mathrm{M}\left[{ }^{3} \mathrm{H}\right]$ kynurenine (2.4 nCi), 1 mм pyruvate, and $80 \mu \mathrm{M}$ pyridoxal-5-phosphate. Samples were incubated for 24 hr at $37^{\circ} \mathrm{C}$, and the reaction was terminated by adding $50 \%(\mathrm{w} / \mathrm{v})$ trichloroacetic acid. The denatured protein was removed by centrifugation, and $1 \mathrm{ml}$ of the resulting supernatant was added to a Dowex $50 \mathrm{~W} \mathrm{H}^{+}$cation exchange column. After successive washes with $0.1 \mathrm{M} \mathrm{HCl}$ and distilled water, $\left[{ }^{3} \mathrm{H}\right]$ KYNA was eluted from the column with $2 \times 1 \mathrm{ml}$ of distilled water and quantified by liquid scintillation spectrometry (Guidetti et al., 1997).

\section{Measurement of kynurenine, quinolinic acid, and KYNA levels in} the brain

Animals were anesthetized in a $\mathrm{CO}_{2}$ atmosphere and killed by decapitation. Their brains were rapidly removed from the skull and placed on ice. The hippocampi were dissected out, placed on dry ice, and stored at $-80^{\circ} \mathrm{C}$. On the day of the assay, the tissue was thawed and homogenized $(1: 10, \mathrm{w} / \mathrm{v})$ in ultrapure water. Aliquots $(100-200 \mu \mathrm{l})$ of the homogenates were diluted to $450 \mu$ l. Then, internal standard (deuterated KYNA, $50 \mu \mathrm{l})$ was added, and the solution was acidified with $\mathrm{HCl}(100 \mu \mathrm{l}, 5 \mathrm{~N})$. To remove fatty compounds, chloroform $(500 \mu \mathrm{l})$ was added to the acidified aliquots. After centrifugation $(10 \mathrm{~min}, 10,000 \times \mathrm{g})$, a $500 \mu \mathrm{l}$ aliquot of the supernatant was applied to a Dowex $50 \mathrm{~W} \mathrm{H}^{+}$column. The column was washed successively with $\mathrm{HCl}(200 \mu \mathrm{l}, 1 \mathrm{~N})$, distilled water $(500 \mu \mathrm{l})$, and methanol (500 $\mu \mathrm{l}, 50 \%$ in water), and KYNA was eluted with methanol ( $2 \mathrm{ml}, 50 \%$ in water). Tetrabutylammonium hydrogen sulfate $(50 \mu \mathrm{l})$ was added to $1 \mathrm{ml}$ of the eluate, and the solution was evaporated to dryness. The samples were then reacted with $25 \mu \mathrm{l}$ of acetone containing $7.5 \%$ of diisopropylethylamine and 3\% pentafluorobenzyl bromide (PFB-Br) at $60-65^{\circ} \mathrm{C}$ for $15 \mathrm{~min}$. Subsequently, $50 \mu \mathrm{l}$ of decane and $750 \mu \mathrm{l}$ of water were added. The samples were thoroughly mixed, and the decane phase was removed. One microliter of the decane phase was injected into a gas chromatograph. The gas chromatography (GC) with electron capture negative ionization mass spectrometry (MS) system (ThermoFinnigan, San Jose, CA) was a Trace GC coupled with a Trace MS quadrupole mass spectrometer. Chromatographic separation was achieved using a $30 \mathrm{~m}$ Rtx-200MS capillary column $(0.25 \mathrm{~mm}$ inner diameter, $0.5 \mu \mathrm{m}$ film thickness; Restek, Bellafonte, PA) with helium as a carrier gas. A split-splitless injection port ( $1 \mu \mathrm{l}$ injection volume) was used. The temperature program was as follows: $155^{\circ} \mathrm{C}$ for $1.25 \mathrm{~min}$, 
$40^{\circ} \mathrm{C} / \mathrm{min}$ to $240^{\circ} \mathrm{C}, 10^{\circ} \mathrm{C} / \mathrm{min}$ to $325^{\circ} \mathrm{C}, 1 \mathrm{~min}$ at $325^{\circ} \mathrm{C}, 18^{\circ} \mathrm{C} / \mathrm{min}$ to $155^{\circ} \mathrm{C}$, and $1.5 \mathrm{~min}$ at $155^{\circ} \mathrm{C}$, injection port at $250^{\circ} \mathrm{C}$. The GC/MS uses electron capture negative ion chemical ionization mass spectroscopy with methane as the reagent gas. The ion source temperature was $220^{\circ} \mathrm{C}$. Selected ion monitoring was performed by recording the signal of the characteristic di-PFB derivative [mass/charge ratio ( $\mathrm{m} / \mathrm{z}$ ) of 368] (Naritsin et al., 1995).

Levels of quinolinic acid and kynurenine were also quantified by GC/ MS. To this end, the tissue homogenate used for determination of KYNA was further diluted $(1: 2.5, \mathrm{v} / \mathrm{v})$ in water. Fifty microliters of internal standard (100 nм 3,5-pyridinedicarboxylic acid and $200 \mathrm{~nm}$ homophenylalanine) were added to $50 \mu \mathrm{l}$ of homogenate, and proteins were precipitated with $\mathrm{HCl}(25 \mu \mathrm{l}, 5 \mathrm{~N})$. Fatty compounds were removed by extraction with chloroform $(100 \mu \mathrm{l})$. After centrifugation $(10 \mathrm{~min}$, $10,000 \times g), 100 \mu \mathrm{l}$ of the acidic supernatant were added to a glass tube containing $62.5 \mu \mathrm{l}$ of $50 \mathrm{~mm}$ tetrabutylammonium hydrogen sulfate and lyophilized overnight. The samples were then reacted with $25 \mu \mathrm{l}$ of methylene chloride containing 7.5\% of diisopropylethylamine and 3\% PFB-Br at $60-65^{\circ} \mathrm{C}$ for $15 \mathrm{~min}$. Subsequently, $50 \mu \mathrm{l}$ of decane and $750 \mu \mathrm{l}$ of water were added. The samples were thoroughly mixed, and the decane phase was removed. One microliter of the decane phase was injected into the gas chromatograph. Chromatographic separation and GC/MS analysis was achieved using a $30 \mathrm{~m}$ Rtx-5MS capillary column $(0.25 \mathrm{~mm}$ inner diameter, $0.25 \mu \mathrm{m}$ film thickness; Restek) and the same GC/MS instrument, injection port, and ion source temperature as described above for determination of KYNA levels, again using electron capture negative ion chemical ionization. The temperature program was as follows: $155^{\circ} \mathrm{C}$ for $1.25 \mathrm{~min}, 40^{\circ} \mathrm{C} / \mathrm{min}$ to $275^{\circ} \mathrm{C}, 10^{\circ} \mathrm{C} / \mathrm{min}$ to $320^{\circ} \mathrm{C}, 1 \mathrm{~min}$ at $320^{\circ} \mathrm{C}$, injection port at $228^{\circ} \mathrm{C}$. For quinolinic acid and kynurenine, the characteristic $(\mathrm{M}-\mathrm{PFB})^{-}$ions are di-PFB derivatives, with $\mathrm{m} / \mathrm{z}$ of 346 and 387 , respectively (Naritsin et al., 1995).

\section{Assessment of locomotor activity}

Male mutant and WT mice ( $n=10$ animals per group) were assessed for changes in locomotor activity (Reddy et al., 1999). Mice were placed in an open-field arena $(35 \times 42 \mathrm{~cm})$ for a period of $5 \mathrm{~min}$. The floor of the arena was divided into $7 \mathrm{~cm}^{2}$ sectors, and locomotor activity was quantified as the number of sector crossings during the 5 min session. Data were obtained from a videotape by an investigator who was unaware of the genotype of the test animals.

\section{Electrophysiological experiments}

Preparation of hippocampal slices. Slices of $250 \mu \mathrm{m}$ thickness were obtained from the hippocampus of 21 - or 60 -d-old male mice by procedures similar to those described previously for rats (Alkondon and Albuquerque, 2001). Slices were stored at room temperature in artificial CSF (ACSF), which was aerated with $95 \% \mathrm{O}_{2}$ and $5 \% \mathrm{CO}_{2}$ and composed of the following (in mM): $125 \mathrm{NaCl}, 25 \mathrm{NaHCO}_{3}, 2.5 \mathrm{KCl}, 1.25 \mathrm{NaH}_{2} \mathrm{PO}_{4}, 2$ $\mathrm{CaCl}_{2}, 1 \mathrm{MgCl}_{2}$, and 25 glucose. In most experiments, biocytin labeling was used to identify morphologically the neurons from which recordings were obtained (Alkondon and Albuquerque, 2001).

Recordings. Nicotinic whole-cell currents, EPSCs, and IPSCs were recorded from the soma of CA1 pyramidal neurons or SR interneurons according to the standard whole-cell patch-clamp technique (Hamill et al., 1981), using an LM-EPC7 amplifier (List Electronic, Darmstadt, Germany). Pyramidal neurons and SR interneurons in the CA1 field of the slices were visualized by means of infrared-assisted videomicroscopy. In some experiments, recordings were also obtained from neurons in the CA1 pyramidal layer visualized under light microscopy. Agonists were applied to the slices via a U-tube, and antagonists were applied via bath perfusion (Alkondon and Albuquerque, 2001). The U-tube had a pore diameter of $250 \mu \mathrm{m}$ and was positioned $\sim 200 \mu \mathrm{m}$ above the surface of the slice. Signals were filtered at $3 \mathrm{kHz}$ (eight-pole, low-pass Bessel filter) and either recorded on a videotape recorder for later analysis or digitally sampled on-line at 1 or $10 \mathrm{kHz}$ by a microcomputer using the Digidata 1200 or 1322A and the pClamp6 or pClamp9 software (Axon Instruments, Foster City, CA). Slices were superfused with ACSF at $2 \mathrm{ml} / \mathrm{min}$. Nominally $\mathrm{Mg}^{2+}$-free ACSF was used in experiments in which NMDAevoked whole-cell currents were studied. Atropine ( $1 \mu \mathrm{M})$ was included in the ACSF in all experiments to inhibit muscarinic receptors. In some experiments, bicuculline $(10 \mu \mathrm{M})$ was added to the ACSF to block $\mathrm{GABA}_{\mathrm{A}}$ receptors. Patch pipettes were pulled from borosilicate glass capillary (1.2 $\mathrm{mm}$ outer diameter) and, when filled with internal solution, had resistances between 3 and $6 \mathrm{M} \Omega$. The series resistance ranged from 8 to $20 \mathrm{M} \Omega$. At $-68 \mathrm{mV}$, the leak current was generally between 25 and 100 pA. Data were not included in the analysis when the leak current exceeded $150 \mathrm{pA}$. For most voltage-clamp recordings, the internal solution contained $0.5 \%$ biocytin in addition to the following (in mM): 10 EGTA, $10 \mathrm{HEPES}, 130 \mathrm{Cs}$-methane sulfonate, $10 \mathrm{CsCl}, 2 \mathrm{MgCl}_{2}$, and 5 lidocaine $\mathrm{N}$-ethyl bromide (QX-314). The $\mathrm{pH}$ was adjusted to 7.3 with $\mathrm{CsOH}$, and the osmolarity was $340 \mathrm{mOsm}$. In experiments in which GABA-evoked currents were studied, the internal solution contained the following (in mM): $120 \mathrm{CsCl}, 10$ HEPES, 10 EGTA, $2 \mathrm{MgCl}_{2}$, and 5 QX-314, $\mathrm{pH}$ adjusted to 7.3 with $\mathrm{CsOH}$. Membrane potentials were corrected for liquid junction potentials. In some neurons, recordings of fast current transients (the counterparts of action potentials under voltage clamp) were initially obtained under cell-attached configuration before entering into the whole-cell configuration. Thus, the ability of nicotinic agonists to trigger action potential firing in the interneurons could be assessed without altering the intracellular environment. All experiments were performed at room temperature $\left(20-22^{\circ} \mathrm{C}\right)$.

Data analysis. The frequency, peak amplitude, $10-90 \%$ rise time, and decay-time constants $\left(\tau_{\text {decay }}\right)$ of EPSCs mediated by NMDA and AMPA receptors were analyzed using the WinEDR V2.3 (Strathclyde Electrophysiology Software, Glasgow, Scotland). The net charge of the NMDA component of EPSCs as well as the amplitude and/or net charge of whole-cell currents evoked by different agonists were calculated using the pClamp9 software. The Mini Analysis software (Synaptosoft, Leonia, $\mathrm{NY}$ ), which uses a threshold-based event-detection algorithm, was also used to analyze IPSCs recorded from CA1 pyramidal neurons. Frequencies and amplitudes of IPSCs were measured in 5 min recordings. Area and amplitude thresholds were set above the noise level and kept constant in each experiment. Events that did not show a typical synaptic waveform were rejected manually. Histograms of IPSC amplitude distributions were made from measurements of amplitude versus number of events. In the histograms, the amplitudes were grouped in $3 \mathrm{pA}$ bins. Cumulative distributions of IPSC amplitudes and interevent intervals, which make no assumption regarding the transmitter release process, were analyzed and compared using the nonparametric KolmogorovSmirnov (K-S) test.

\section{Binding studies}

Membrane preparation. Hippocampi were homogenized in $2 \mathrm{ml}$ of icecold HBSS containing antiproteases ( $2 \mathrm{~mm}$ PMSF, $1 \mu \mathrm{g} / \mathrm{ml}$ pepstatin A, 2 $\mu \mathrm{g} / \mathrm{ml}$ aprotinin, and $0.3 \mu \mathrm{g} / \mathrm{ml}$ leupeptin), and the homogenates were centrifuged at $4000 \times g$ at $4^{\circ} \mathrm{C}$ for $15 \mathrm{~min}$. The tissue pellets were resuspended in antiprotease-containing HBSS $(2 \mathrm{ml})$ and freeze thawed five times using liquid nitrogen. The suspensions were then centrifuged at $12,000 \times g$ at $4^{\circ} \mathrm{C}$ for $15 \mathrm{~min}$, and the membrane pellets were resuspended in the antiprotease-containing HBSS $(1 \mathrm{ml})$ and stored at $-80^{\circ} \mathrm{C}$ until needed. Protein levels were determined on $\mathrm{SDS} / \mathrm{NaOH}(0.1 \% / 0.1 \mathrm{M})$ solubilized membranes using the Micro BCA protein assay (Pierce, Rockford, IL); bovine serum albumin was the standard.

Binding assay. Binding assays were performed on $100 \mu \mathrm{g}$ of membrane suspension in $0.25 \mathrm{ml}$ of HBSS containing $0.1 \%$ BSA with $\left[{ }^{125} \mathrm{I}\right] \alpha$-BGT $(20 \mathrm{~nm})$ or $\left[{ }^{3} \mathrm{H}\right]$ epibatidine $(10 \mathrm{nM})$. Nonspecific binding was determined by addition of cold $\alpha$-BGT $(2 \mu \mathrm{M})$ or cold epibatidine $(100 \mu \mathrm{M})$ before the addition of the corresponding radioactive ligand. The samples were incubated on a rocker platform at $4^{\circ} \mathrm{C}$ for $90 \mathrm{~min}$ and subsequently transferred to glass microfiber filters that had been soaked for at least $3 \mathrm{hr}$ in HBSS containing $0.5 \%$ polyethyleneimine. The filters were then washed with cold HBSS $(20 \mathrm{ml})$ and placed in tubes for counting. Each sample was assayed in triplicate.

\section{Quantification of dendritic arborizations}

In most experiments, biocytin labeling was used to identify morphologically the neurons from which recordings were obtained (Alkondon and 
Albuquerque, 2001). The Neurolucida software was used to measure the length of dendrites of neurons from which electrophysiological recordings were obtained.

Drugs and toxins used

ACh chloride, DL-2-amino-5-phosphonovaleric acid (APV), (-)bicuculline methiodide, choline chloride, tetrodotoxin (TTX), QX-314, atropine sulfate, and $\alpha$-BGT were obtained from Sigma (St. Louis, MO). 6-Cyano-7nitroquinoxaline-2,3-dione (CNQX) was purchased from Research Biochemicals (Natick, MA). MLA citrate was a gift from Professor M. H. Benn (Department of Chemistry, University of Calgary, Alberta, Canada). Dihydro- $\beta$ erythroidine. $\mathrm{HBr}$ and $( \pm)$ mecamylamine. $\mathrm{HCl}$ were gifts from Merck, Sharp \& Dohme (Rahway, NJ). Stock solutions of all drugs, except KYNA, were made in distilled water. Stock solution of KYNA was made in dimethylsulfoxide (DMSO). $\left[{ }^{3} \mathrm{H}\right]$ Kynurenine (specific activity, $9.3 \mathrm{Ci} / \mathrm{mmol}$ ) was purchased from Amersham Biosciences (Arlington Heights, IL). [ $\left.{ }^{125} \mathrm{I}\right] \alpha$-BGT (specific activity, $143 \mathrm{Ci} / \mathrm{mmol}$ ) and $\left[{ }^{3} \mathrm{H}\right]$ epibatidine (specific activity, $56.2 \mathrm{Ci} / \mathrm{mmol}$ ) were purchased from PerkinElmer Life Sciences (Boston, MA). The rabbit anti-human KAT II antibody was kindly provided to us by Dr. Etsuo Okuno (Wakayama Medical College, Wakayama, Japan).

\section{Results}

\section{Genotypic and phenotypic}

characterization of $\mathrm{mKat}-2^{-/-}$mice

Targeted deletion of the $m$ Kat-2 gene (Fig. $1 A$ ) was verified by PCR and Northern analyses. The results indicated that $m$ Kat -2 expression was disrupted in the $m$ Kat- $2^{-/-}$mice (Fig. $1 B, C$ ). In addition, immunotitration of enzymatic activity revealed that KAT II activity was absent in hippocampal extracts of $m K a t-2^{-/-}$mice (Fig. 1D). It should be noted that, in the adult rat brain, KAT II accounts for $\sim 70 \%$ of total KAT activity (Guidetti et al., 1997). In the hippocampus of adult mice, however, KAT II activity represents only $10 \%$ of total KAT activity (Fig. 1D). Mouse brain KAT II activity was found to be substantially more important during the first month of postnatal development, contributing $\sim 40 \%$ to total KAT activity (Fig. $1 D$ ). This ontogenetic pattern of enzyme activity translated into $\sim 55 \%$ reduction of hippocampal KYNA levels in 21-d-old mKat-2 ${ }^{-1-}$ mice compared with WT mice, whereas no such decrease was seen in 60-d-old mutant mice (Fig. 2C). Across ages, levels of the KYNA precursor kynurenine and of quinolinic acid, another major kynurenine metabolite, were very similar in hippocampal tissue of WT and $m \mathrm{Kat}_{-} 2^{-/-}$mice (Fig. $2 A, B$ ).

Weight, food, and water intake were not significantly different between $m \mathrm{Kat}_{-2^{-/-}}$and WT mice at any given age (data not shown). In contrast, up to $28 \mathrm{~d}$ of age, $m \mathrm{Kat}^{-2^{-/}}$mice showed more spontaneous locomotor activity than age- and strainmatched WT mice. Quantification of the locomotor activity in an open-field arena revealed that 21 -d-old $m \mathrm{Kat}^{-2^{-1}}$ mice crossed the sectors in the arena twice as frequently as WT mice (Fig. 2D). At $60 \mathrm{~d}$ of age, however, the frequency of sector crossings for $m K a t-2^{-\prime-}$ and WT mice was not significantly different (Fig. 2D).
B

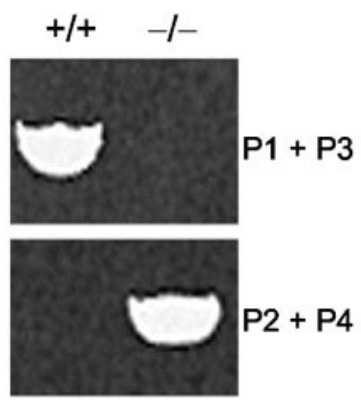

Targeted allele

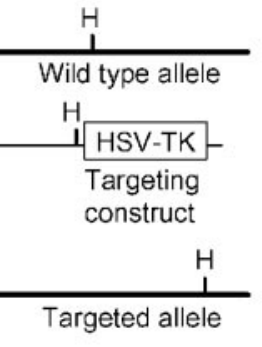

D

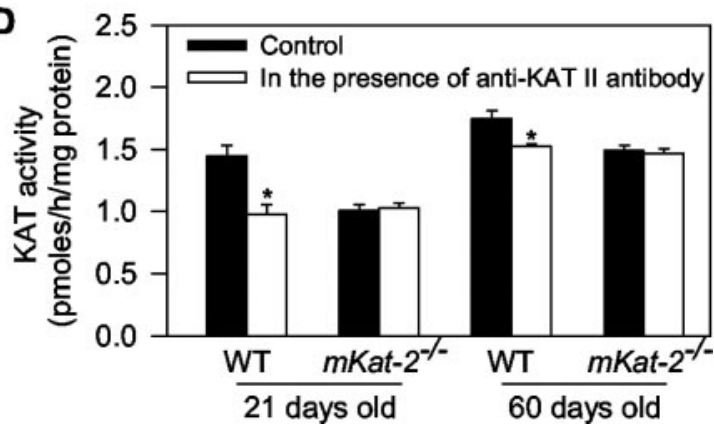

Figure 1. Genotypic characterization of $m K a t-2^{-/-}$mice. $A$, Schematic representation of the targeting and PCR strategy used for generating and genotyping $m K a t-2^{-/-}$mice. $B$, Genotype of the mice was verified by PCR using two pairs of primers as (tvily. The restriction enzyme cleavage sites are indicated with $\mathrm{H}$ (Hind IIII), B (BamHI), and K (Kpnl). C, Northern blot analysis using on each lane was indicated by the $18 \mathrm{~S}$ ribosomal RNA. D, Immunotitration of KAT activity in hippocampal extracts from WT and $m$ Kat $-2^{-/-}$mice at 21 and $60 \mathrm{~d}$ of age. At postnatal days 21 and 60 , a rabbit anti-human KAT II antibody was used to immunoprecipitate KAT II in hippocampal extracts from WT and $m K^{\prime} \mathrm{t}_{-2^{-/-}}$mice. Total KAT activity (control) in each animal group was compared with the corresponding KAT activity measured in the presence of the anti-KAT II antibody. Graph and error bars represent mean and SEM, respectively, of results obtained from three animals per experimental group. ${ }^{*} p<0.05$ by two-way ANOVA.
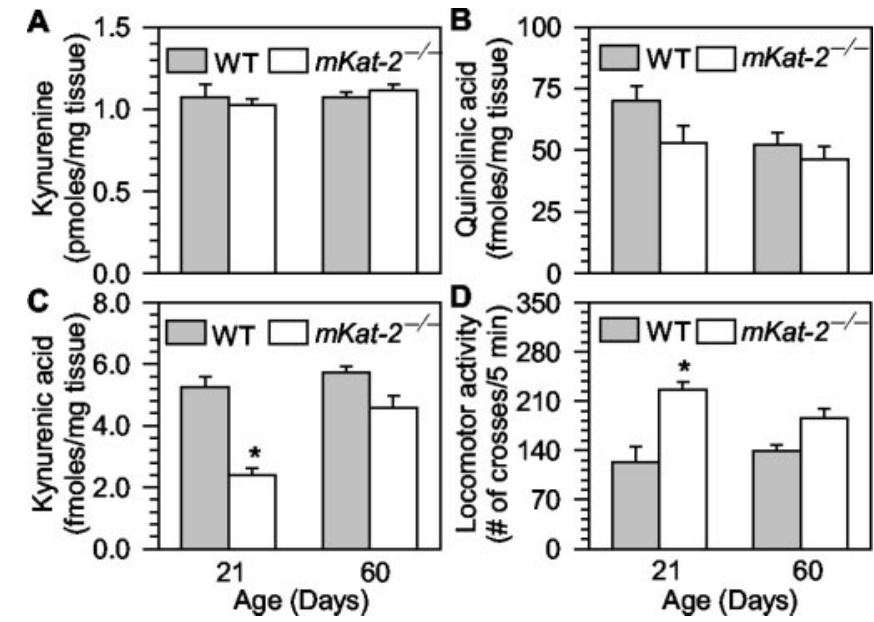

Figure 2. Phenotypic characterization of 21- and 60-d-old mice with disrupted $m$ Kat-2 expression. Graphs show levels of kynurenine $(A)$, quinolinic acid $(B)$, and KYNA ( $C$ ) in the hipppocampi of WT and $m K K_{t-} 2^{-1-}$ mice at 21 and $60 \mathrm{~d}$ of age. Graph and error bars represent mean and SEM, respectively, of results obtained from five to nine animals in each group. $D$, Locomotor activity of 21- and 60-d-old WT and $m K a t-2^{-1-}$ mice was analyzed in a mouse Tru Scan Activity Monitor (Coulbourn Instruments, Allentown, PA) according to the procedure described in Material and Methods. Graph and error bars are the mean and SEM, respectively, of results obtained from 17 WT and $18 \mathrm{mKat}-2^{-/-}$mice. The same WT and mKat- $2^{-1-}$ mice were tested across ages. ${ }^{*} p<0.05$ by two-way ANOVA, followed by Bonferroni post hoc test. 


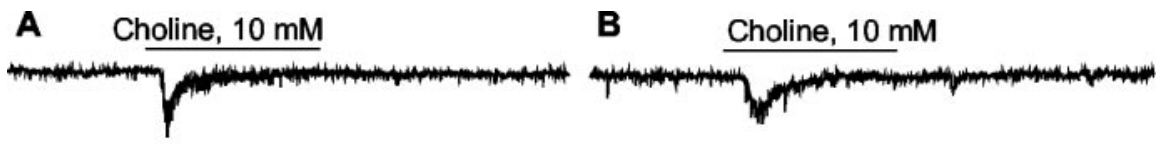

In the presence of $\alpha$-BGT, $100 \mathrm{nM}$

In the presence of MLA, $20 \mathrm{nM}$

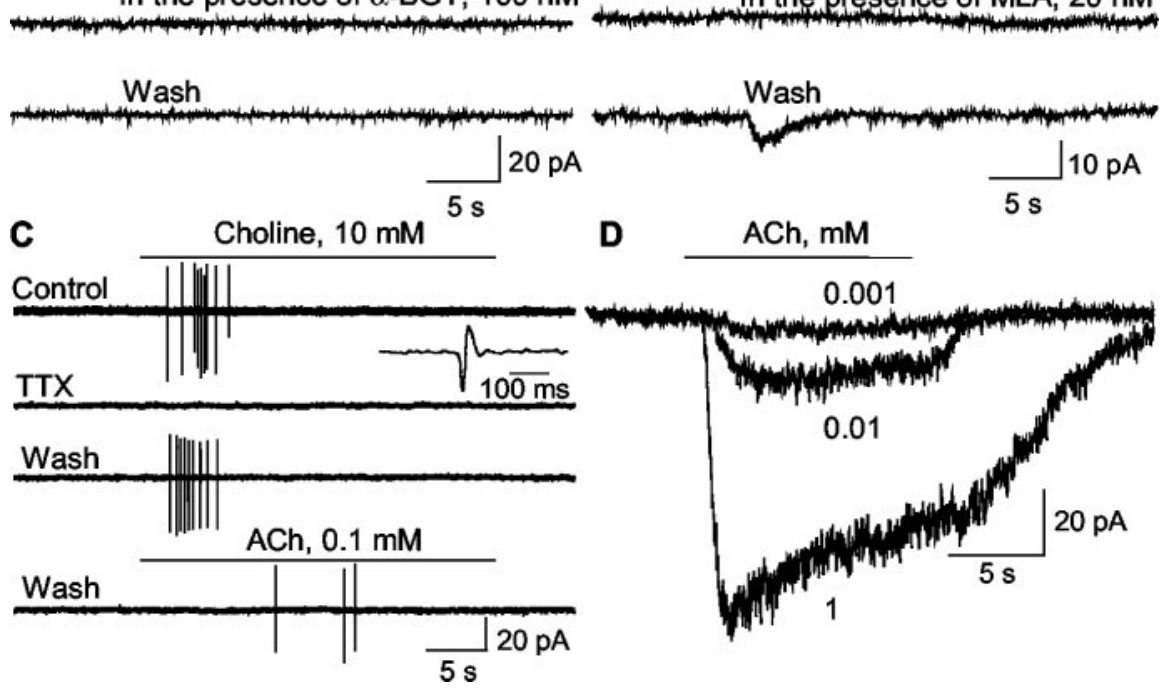

Figure 3. Pharmacological characterization of somatodendritic $n A C h R s$ present in CA1 SR interneurons of WT and $m K a t-2^{-/-}$ mice. A, Sample recordings of whole-cell currents evoked by U-tube application of choline $(10 \mathrm{~mm})$ to a CA1 SR interneuron at $-68 \mathrm{mV}$ under control condition (top trace), in the presence of $\alpha$-BGT (50 nM) after $10 \mathrm{~min}$ exposure of the hippocampal slice to the toxin (middle trace), and after 20 min of washing the preparation with $\alpha$-BGT-free ACSF (bottom trace). B, Sample recordings of choline-evoked whole-cell currents obtained from another CA1 SR interneuron at $-68 \mathrm{mV}$ before (top trace), during (middle trace), and after exposure of the hippocampal slice to MLA (10 nM). Exposure to MLA lasted 8-10 min, and the washing phase lasted $20 \mathrm{~min}$. C, Sample recordings obtained from a CA1 SR interneuron under cell-attached configuration using a nominally $\mathrm{Mg}^{2+}$-free ACSF. U-tube application of choline to this neuron triggered action potentials that were recorded as fast-current transients and could not be detected after 5 min exposure of the hippocampal slice to TTX (100 nM). After a 5 min wash of the slice with TTX-free ACSF, choline $(10 \mathrm{~mm})$ or ACh $(0.1 \mathrm{~mm})$ triggered action potentials in the same neuron. The longer onset of the response and the smaller number of action potentials seen with $\mathrm{ACh}$ than with choline can be attributed to the difference in the concentration of the agonists. The pipette potential was $-60 \mathrm{mV}$. D, Sample recordings of slowly decaying whole-cell currents triggered by U-tube application of ACh $(1 \mu \mathrm{m}$ to $1 \mathrm{~mm})$ to a CA1 SR interneuron at $-68 \mathrm{mV}$. In all experiments, ACSF contained atropine $(1 \mu \mathrm{M})$ and bicuculline $(10 \mu \mathrm{M})$. Samples shown in this figure were obtained from CA1 SR interneurons of 21-d-old $m K a t-2^{-1-}$ mice and are qualitatively representative of results obtained from hippocampal slices of WT and $m K a t-2^{-1-}$ mice.

Characterization of nicotinic responses recorded from CA1 SR interneurons in hippocampal slices of WT and mKat-2 $2^{-1-}$ mice

Different types of nicotinic responses could be recorded under whole-cell patch-clamp configuration from CA1 SR interneurons in hippocampal slices of WT and $m \mathrm{Kat}-2^{-/-}$mice. In the presence of the $\mathrm{Na}^{+}$-channel blocker TTX (300 nM), 87\% of the interneurons studied ( $n=26$ from 30 animals) responded to choline $(10 \mathrm{~mm})$ with whole-cell currents that decayed to the baseline during the agonist pulse. Considering that these currents were irreversibly blocked by $\alpha$-BGT (100 nM) (Fig. $3 A$ ) and reversibly blocked by MLA (20 nM) (Fig. 3B), they should have resulted from activation of somatodendritic $\alpha 7^{\star}$ nAChRs. In slices obtained from the hippocampi of 21 -d-old mice, these currents had small amplitudes; the amplitudes of the largest responses recorded at $-68 \mathrm{mV}$ from interneurons in 21-d-old WT and $m$ Kat $-2^{-/-}$mice were 16.9 and $26 \mathrm{pA}$, respectively. Nevertheless, $\alpha 7^{\star} \mathrm{nAChR}$ activation in the somatodendritic region of the CA1 SR interneurons was capable of modulating their excitability as demonstrated by the finding that, in $\mathrm{Mg}^{2+}$-free ACSF, U-tube application of choline $(10 \mathrm{mM})$ to interneurons under cell-attached configuration elicited fast-current transients (Fig. $3 C$, top trace and inset) that were reversibly blocked by perfusion of the slices with TTX (100 nM) (Fig. 3C) and, therefore, repre- sented action potentials. In the same neurons, ACh, at a subsaturating concentration for $\alpha 7^{\star}$ nAChRs (0.1 mM), triggered action potentials that had lower frequency and longer delay than those evoked by the saturating concentration of choline (Fig. $3 C)$. The concentration-response relationship for ACh and the finding that both ACh- and choline-triggered action potentials did not outlast the duration of the agonist pulse supported the notion that the action potentials resulted from activation of somatodendritic $\alpha 7^{\star}$ nAChRs in the interneurons.

A small population of the CA1 SR interneurons studied at $-68 \mathrm{mV}$ in the presence of TTX ( 3 of 16 neurons from 9 WT animals) responded to ACh (up to $1 \mathrm{~mm}$ ) with slowly desensitizing currents (Fig. $3 D)$. At a concentration as low as $1 \mu \mathrm{M}$, ACh could evoke these currents (Fig. 3D). The apparent high potency of ACh suggested that the receptors subserving these responses were most likely $\alpha 4 \beta 2^{*}$ nAChRs.

In the absence of TTX, 91\% of the interneurons studied in 21-d-old WT and $m$ Kat $-2^{-1-}$ mice ( $n=32$ from 35 animals) responded to ACh with EPSCs that were recorded under the whole-cell mode of the patch-clamp technique (Fig. 4). In interneurons that were voltage clamped at $-68 \mathrm{mV}$ and continuously perfused with ACSF containing $1 \mathrm{~mm}$ extracellular $\mathrm{Mg}^{2+}$ and $10 \mu \mathrm{M}$ bicuculline, ACh triggered EPSCs that had an average $\tau_{\text {decay }}$ of $2.8 \pm$ $0.32 \mathrm{msec}$ ( $n=12$ neurons) (Fig. $4 A$ ) and could be blocked by the AMPA receptor antagonist CNQX (10 $\mu \mathrm{M})$ (Fig. 4A). The pharmacological and kinetic properties of these EPSCs indicated that they were glutamatergic events mediated by AMPA receptors (Arancio et al., 1994; Alkondon et al., 2003a). At $+40 \mathrm{mV}$, however, ACh-elicited EPSCs had an average $\tau_{\text {decay }}$ of $206 \pm 26 \mathrm{msec}(n=13$ neurons) (Fig. $4 B$ ); $>95 \%$ of these currents could be blocked by the NMDA receptor antagonist APV $(50 \mu \mathrm{M})$ (Fig. $4 \mathrm{~B})$. The pharmacological and kinetic properties of the majority of ACh-evoked EPSCs recorded at +40 $\mathrm{mV}$ were characteristic of glutamatergic events mediated by NMDA receptors (Alkondon et al., 2003a). In the nominal absence of extracellular $\mathrm{Mg}^{2+}$, spontaneously occurring and AChtriggered EPSCs recorded from CA1 interneurons at any membrane potential were mediated primarily by NMDA receptors, because they could be blocked by APV ( $50 \mu \mathrm{M}$; data not shown). The ability of ACh to trigger NMDA EPSCs in the presence (Fig. $4 C$ ) or in the nominal absence of extracellular $\mathrm{Mg}^{2+}$ was inhibited by mecamylamine. Measurements of the net charge of EPSCs triggered by ACh in the presence and in the absence of $1 \mu \mathrm{M}$ mecamylamine revealed that this antagonist reduced by $89 \pm$ $4.4 \%$ the ACh response ( $n=6$ neurons). Previous studies have demonstrated that 0.3 and $1 \mu \mathrm{M}$ mecamylamine reduced by $\sim 50$ and $80 \%$, respectively, the activity of native $\alpha 3 \beta 4^{\star}$ nAChRs or ectopically expressed $\alpha 3 \beta 4$ nAChRs (Papke et al., 2001; Alkondon et al., 2003a). Other nAChR subtypes are far less sensitive to 
A
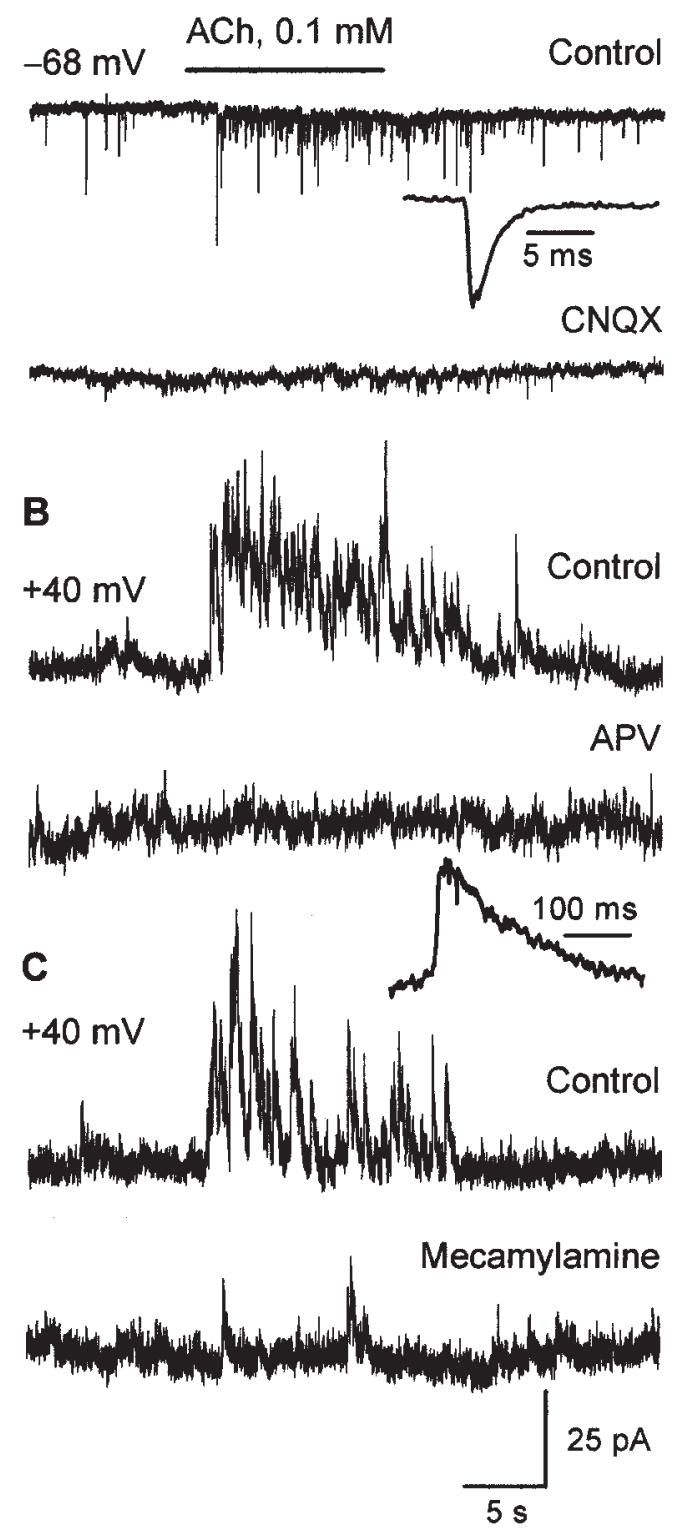

Figure 4. Pharmacological characterization of $n A C h R s$ that modulate glutamate release onto CA1 SR interneurons of WT and $m K a t-2^{-/-}$mice. A, Sample recordings of ACh (0.1 mm)triggered EPSCS obtained from a CA1 SR interneuron at $-68 \mathrm{mV}$ before (top trace) and after (bottom trace) 8-10 min of perfusion of the hippocampal slice with CNQX (10 $\mu \mathrm{m}$ )-containing ACSF. The average of the ACh-triggered EPSCs is shown in an expanded scale that reveals the fast decaying kinetics characteristic of AMPA EPSCS. B, Sample recordings of ACh-evoked EPSCS obtained from the same interneuron at $+40 \mathrm{mV}$ before (top trace) and after (bottom trace) 8-10 min of perfusion of the hippocampal slice with APV (50 $\mu \mathrm{m})$-containing ACSF. The averaged ACh-triggered EPSCs shown in an expanded scale reveals the slow decaying kinetics that characterizes glutamatergic events mediated by NMDA receptors. C, Sample recordings of AChtriggered EPSCs obtained from the same interneuron at $+40 \mathrm{mV}$ before (top trace) and after (bottom trace) $10 \mathrm{~min}$ of perfusion of the hippocampal slice with ACSF containing mecamylamine $(1 \mu \mathrm{M})$. In the presence of mecamylamine $(1 \mu \mathrm{M})$, ACh was unable to trigger EPSCs in the interneuron held at $+40 \mathrm{mV}$. All recordings were obtained using ACSF containing $\mathrm{Mg}^{2+}(1 \mathrm{~mm})$, atropine $(1 \mu \mathrm{m})$, and bicuculline $(10 \mu \mathrm{m})$. Samples shown in this figure were obtained from a CA1 SR interneuron of a 21-d-old WT mouse and are qualitatively representative of results obtained from hippocampal slices of WT and $m K a t-2^{-/-}$mice.

blockade by mecamylamine (Papke et al., 2001). Thus, the present results lead to the conclusion that glutamate release onto the CA1 SR interneurons in hippocampal slices from $129 \mathrm{SvEv}$ mice is regulated by presynaptically located $\alpha 3 \beta 4^{\star} \mathrm{nAChRs}$ and is capable of activating both postsynaptic NMDA and AMPA receptors. Similar results have been obtained from CA1 SR interneurons of rat hippocampal slices (Alkondon and Albuquerque, 2002; Alkondon et al., 2003a).

Responses triggered in CA1 SR interneurons of mouse hippocampal slices by activation of somatodendritic $\alpha 7^{\star}$ nAChRs, preterminal-presynaptic $\alpha 3 \beta 4^{\star}$ nAChRs, and somatodendritic $\mathrm{GABA}_{\mathrm{A}}$ and NMDA receptors

The decay phase of $\alpha 7^{\star}$ nAChR-mediated whole-cell currents triggered by application of choline $(10 \mathrm{~mm})$ to CA1 SR interneurons in hippocampal slices of 21 -d-old WT and $m$ Kat- $2^{-/-}$mice (Fig. 5A) did not differ significantly; the $\tau_{\text {decay }}$ of currents recorded at $-68 \mathrm{mV}$ from neurons in slices of WT and $\mathrm{mKat}-2^{-1-}$ mice were $1511 \pm 222 \mathrm{msec}(n=8$ neurons $)$ and $1413 \pm 234$ $\operatorname{msec}(n=16$ neurons), respectively. However, the amplitude and net charge of the currents recorded from CA1 SR interneurons in slices of 21-d-old WT mice were significantly smaller than those of currents recorded from the interneurons in slices of 21-d-old $m$ Kat- $2^{-/-}$mice (Fig. 5B). Choline-evoked currents in CA1 SR interneurons of WT mice ranged from 2 to $16.9 \mathrm{pA}$ in amplitude and from 2 to $35 \mathrm{pC}$ in net charge (Fig. 5B). In contrast, choline-evoked currents recorded from CA1 SR interneurons of $m$ Kat $-2^{-1-}$ mice ranged from 8 to $26 \mathrm{pA}$ in amplitude and from 10 to $46 \mathrm{pC}$ in net charge (Fig. $5 B$ ). The $\alpha 7^{\star}$ nAChR activity in CA1 SR interneurons of 21 -d-old $m \mathrm{Kat}-2^{-/-}$mice may have increased as a direct and/or indirect result of the decreased hippocampal levels of KYNA. It could also have increased because of an enhancement in the number of surface $\alpha 7 \mathrm{nAChRs}$.

To determine whether the number of surface $\alpha 7^{\star}$ nAChRs changed with the age of the animals and/or as a consequence of the targeted mutation, a filter binding assay using $\left[{ }^{125} \mathrm{I}\right] \alpha$-BGT was performed on hippocampal membrane preparations from 21 - and 60-d-old WT and $m$ Kat- $2^{-/-}$mice. Across ages and animals, $\left[{ }^{125} \mathrm{I}\right] \alpha$-BGT binding to the membrane preparations was comparable (Table 1). These results indicated that the higher $\alpha 7^{\star}$ nAChR activity observed in CA1 SR interneurons of 21-d-old $m$ Kat $-2^{-/-}$mice may not have arisen from an increased number of surface $\alpha 7^{\star}$ nAChRs. Similarly, levels of binding of the selective $\alpha 4 \beta 2^{*}$ nAChR ligand $\left[{ }^{3} \mathrm{H}\right]$ epibatidine to hippocampal membrane preparations of 21 -d-old $m K a t-2^{-/-}$and WT mice were not significantly different (Table 1), suggesting that disruption of $m$ Kat-2 expression did not alter the number of surface $\alpha 4 \beta 2^{*}$ nAChRs in the hippocampus. It should be noted, however, that region- and/or cell-specific changes in nAChR expression could have been missed, because the binding assay was performed on membrane preparations from whole hippocampi.

Quantification of the activity of presynaptically located $\alpha 3 \beta 4^{*}$ nAChRs in the mouse hippocampus was made possible by the analysis of net charge carried by NMDA EPSCs triggered by ACh in CA1 SR interneurons using nominally $\mathrm{Mg}^{2+}$-free ACSF (Fig. $6 A)$. At +40 and $-68 \mathrm{mV}$, the net charge carried by AChtriggered NMDA EPSCs in CA1 SR interneurons of 21-d-old WT mice was similar to that recorded from interneurons of agematched $m$ Kat- $2^{-1-}$ mice (Fig. 6A,B). Likewise, the net charge carried by whole-cell currents evoked by application of GABA $(20 \mu \mathrm{M})$ or NMDA $(50 \mu \mathrm{M})$ plus glycine $(10 \mu \mathrm{M})$ to CA1 SR interneurons of 21-d-old WT mice was comparable with that of currents recorded from interneurons of age-matched $m \mathrm{Kat}-2^{-/-}$ mice (Fig. 6C). We therefore concluded that the activities of NMDA and $\mathrm{GABA}_{\mathrm{A}}$ receptors in CA1 SR interneurons and of $\alpha 3 \beta 4^{\star} \mathrm{nAChRs}$ regulating glutamate release onto these interneurons were not affected by the targeted mutation. 
A WT

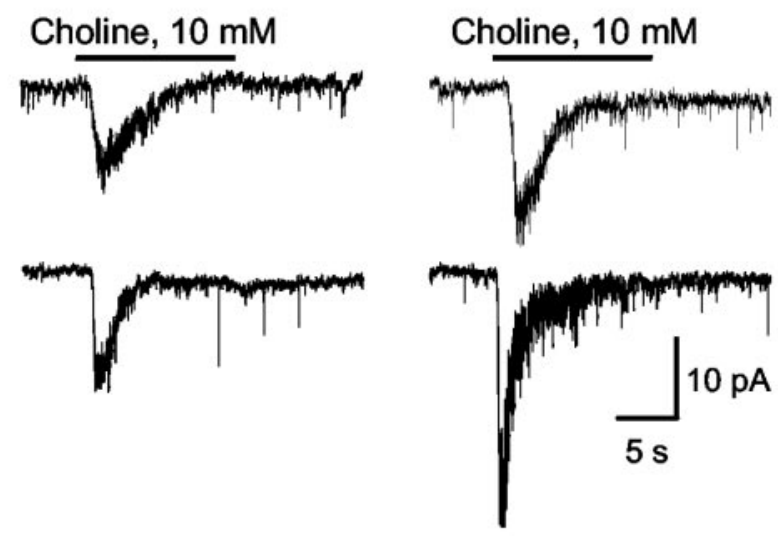

rons at $-68 \mathrm{mV}$ were primarily mediated by AMPA receptors. The kinetics of AMPA EPSCs recorded from CA1 SR interneurons of the hippocampi of 21-d-old WT and $m \mathrm{Kat}-2^{-1-}$ mice were very similar (Table 2). Likewise, the frequency and peak amplitude of AMPA EPSCs recorded from CA1 SR interneurons were not affected by the targeted mutation (Table 2).

Recordings obtained from CA1 pyramidal neurons at $0 \mathrm{mV}$, in the absence of bicuculline, contained primarily outward events (Fig. $7 A, B$ ) that were GABAergic in nature, because they could be blocked by the $\mathrm{GABA}_{\mathrm{A}}$ receptor antagonist picrotoxin $(100 \mu \mathrm{M})$. In addition, these events had an average $\tau_{\text {decay }}$ of $48 \mathrm{msec}$ (Table 3 ), which is similar to that reported for GABAergic IPSCs recorded from rat hippocampal neurons (Alkondon et al., 1999; Alkondon and Albuquerque, 2001). The $\tau_{\text {decay }}$ of IPSCs recorded from CA1 pyramidal neurons of 21-d-old WT mice were comparable with those of IPSCs recorded from CA1 pyramidal neurons of age-matched $m$ Kat $-2^{-/-}$mice (Table 3 ). However, the frequency and amplitudes of IPSCs recorded from CA1 pyramidal neurons were significantly higher in $m K a t-2^{-/-}$than in WT mice (Fig. 7 A, B; Table 3).

To determine how GABAergic transmission was affected by the targeted mutation, histograms and cumulative plots of IPSC amplitude were analyzed. To minimize contamination of IPSCs with baseline noise, the threshold for event detection was set to be $5 \mathrm{pA}$ (approximately four times the root mean square noise level). The distributions of IPSC amplitudes recorded from CA1 pyramidal neurons of both 21 -d-old WT and $m K a t-2^{-1-}$ mice were similarly skewed toward larger events (Fig. 8A). Higher frequencies and amplitudes of IPSCs recorded from CA1 pyramidal neurons of $m \mathrm{Kat}-2^{-/-}$compared with WT mice were demonstrated quantitatively in cumulative probability plots of interevent intervals and IPSC amplitudes (Fig. $8 \mathrm{~B}$ ). There was a significant shift toward larger amplitudes in the cumulative probability of IPSC amplitudes recorded from $m$ Kat $-2^{-/-}$neurons compared with WT neurons (Fig. $8 \mathrm{~B}$ ). There was also a highly significant shift toward shorter interevent intervals in the cumulative probability of interevent intervals recorded from $\mathrm{mKat}-2^{-/-}$neurons compared with WT neurons (Fig. $8 B$ ).

At $60 \mathrm{~d}$ of age, when levels of KYNA in the brain of $m \mathrm{Kat}_{-} 2^{-1-}$ and WT mice were comparable, the frequencies and amplitudes of IPSCs recorded from CA1 pyramidal neurons in hippocampal slices of either group of animals were very similar. The frequencies of IPSCs recorded from 13 neurons of 60-d-old WT and $m$ Kat $-2^{-/-}$mice were $1.70 \pm 0.26$ and $1.91 \pm 0.33 \mathrm{~Hz}$ (mean \pm SEM), respectively. Thus, no significant differences were observed in the cumulative probability plots of interevent intervals or IPSC amplitudes recorded from 60-d-old WT and $m \mathrm{Kat}-2^{-1-}$ mice (Fig. 8C). hippocampal slices from WT and $m$ Kat- $2^{-1-}$ mice. Two representative samples in each group are shown. ACSF contained $\mathrm{Mg}^{2+}(1 \mathrm{~mm})$, atropine $(1 \mu \mathrm{M})$, and bicuculline $(10 \mu \mathrm{M})$. B, Top graph summarizes the mean \pm SEM values of peak amplitude and net charge of cholineevoked currents in interneurons from WT and $m$ Kat- $2^{-1-}$ mice. Numbers of neurons studied in each animal group are shown in parentheses. The number of neurons included in the analysis of net charge was in general lower than the number of neurons included in the analysis of the peak current amplitude attributable to contamination of the recordings with glutamatergic synaptic events. Statistical significance was determined using the unpaired Student's $t$ test. The bottom graph shows the distribution of individual values of peak amplitude and net charge of cholineevoked currents in the two animal groups.

Synaptic transmission in the CA1 field of the hippocampi of WT and $m$ Kat $-2^{-1-}$ mice

As mentioned above, in the presence of $1 \mathrm{~mm}$ extracellular $\mathrm{Mg}^{2+}$ and $10 \mu \mathrm{M}$ bicuculline, EPSCs recorded from CA1 SR interneu-

Effects of the NMDA receptor antagonist APV, the $\alpha 7 \mathrm{nAChR}$ antagonist $\alpha$-BGT, and KYNA on the frequencies and amplitudes of spontaneous IPSCs recorded from CA1 pyramidal neurons of $\mathbf{m K a t}-2^{-/-}$and WT mice

To investigate the contribution of NMDA receptors to modulation of synaptic transmission between GABAergic neurons and CA1 pyramidal neurons in WT and $m$ Kat $-2^{-1-}$ mice, IPSCs were recorded from CA1 pyramidal neurons in either the presence or absence of the NMDA receptor antagonist APV $(100 \mu \mathrm{M})$. Cumulative probability plots of interevent intervals and amplitudesof IPSCs recorded in the absence and in the presence of APV 
from pyramidal neurons of WT mice were not significantly different (Fig. 9A). The higher frequencies and amplitudes of IPSCs recorded from CA1 pyramidal neurons of $m \mathrm{Kat}-2^{-1-}$ mice could not be accounted for by increased NMDA receptor activity resulting directly and/or indirectly from decreased levels of KYNA in the brain of these mice, because cumulative probability plots of interevent intervals and amplitudes of IPSCs recorded in the absence and in the presence of APV from the CA1 pyramidal neurons in hippocampal slices of $m \mathrm{Kat}-2^{-/-}$mice were also superimposable (Fig. $9 \mathrm{~B}$ ).

No significant difference existed between cumulative probability plots of interevent intervals and amplitudes of IPSCs recorded from CA1 pyramidal neurons of WT mice in the presence or in the absence of the $\alpha 7^{\star}$ nAChR antagonist $\alpha$-BGT (100 nM) (Fig. 9C). In the absence and in the presence of $\alpha$-BGT (100 nM), the average IPSC frequencies recorded from neurons of four WT mice were $1.9 \pm 0.28 \mathrm{~Hz}(n=12$; mean \pm SEM $)$ and $1.7 \pm 0.46$ $\mathrm{Hz}(n=7$; mean $\pm \mathrm{SEM})$, respectively. In contrast, a $10 \mathrm{~min}$ exposure to $\alpha$-BGT ( $100 \mathrm{nM}$ ) reduced the frequencies and amplitudes of IPSCs recorded from CA1 pyramidal neurons of $m$ Kat $-2^{-/-}$mice, causing a significant shift to the right in the cumulative plot of interevent intervals and a significant shift to the left in the cumulative plots of IPSC amplitudes (Fig. 9D). In the absence of $\alpha$-BGT, the average frequency and amplitudes of IPSCs recorded from CA1 pyramidal neurons of three mKat $-2^{-1-}$ mice were $3.2 \pm 0.44 \mathrm{~Hz}(n=12$ neurons; mean \pm $\mathrm{SEM})$ and $12.1 \pm 0.26 \mathrm{pA}(n=5608$ events; mean $\pm \mathrm{SEM})$, respectively. After $10 \mathrm{~min}$ of perfusion of the hippocampal slices with ACSF containing $\alpha$-BGT (100 nM), the average frequency and amplitudes of IPSCs decreased to $1.6 \pm 0.32 \mathrm{~Hz}(n=9$ neurons; mean \pm SEM) and $9.7 \pm 0.12 \mathrm{pA}(n=3013$ events; mean \pm SEM), respectively. Results obtained in the presence of $\alpha$-BGT were significantly different from those obtained in the absence of the toxin (Fig. 9D), becoming similar to those obtained from CA1 pyramidal neurons of age-matched WT mice.

The significant reduction of IPSC frequency and amplitude caused by $\alpha$-BGT could be accounted for by a presynaptic reduction of GABA release attributable to blockade of $\alpha 7^{\star}$ nAChRs in GABAergic neurons synapsing onto the neurons under study or a decrease in the activity of postsynaptic $\mathrm{GABA}_{\mathrm{A}}$ receptors. The presynaptic action of $\alpha$-BGT is favored, because numerous studies have reported that this toxin selectively blocks nAChRs (for review, see Albuquerque et al., 1997). The proximal dendritic region of CA1 pyramidal neurons is highly innervated by axons of CA1 SR interneurons (Gulyás and Freund, 1996; Oliva et al., 2000; Buzaski et al., 2003). Thus, it can be concluded that GABA release onto CA1 pyramidal neurons in 21-d-old $m$ Kat $-2^{-1-}$ mice is higher than in age-matched WT mice because the $\alpha 7^{\star}$ nAChR activity in CA1 SR interneurons of the mutant mice is higher than in the interneurons of the WT mice. Similar results were obtained when hippocampal slices of 21-d-old WT or $m$ Kat-2 $2^{-1-}$ mice were exposed in vitro to 100 nм KYNA (Fig. 9E, F).

Because of the slow equilibration of KYNA with $\alpha 7^{\star}$ nAChRs (Hilmas et al., 2001) and the physical barrier imposed by the slice preparation, hippocampal slices were allowed to equilibrate in situ for $1 \mathrm{hr}$ with $100 \mathrm{~nm}$ KYNA before IPSCs were recorded from the pyramidal neurons. The cumulative distributions of inter- event intervals and amplitudes of IPSCs recorded from CA1 pyramidal neurons of WT mice were unaffected by in situ exposure to KYNA (Fig. 9E). In hippocampal slices that were perfused for 1 hr with ACSF containing DMSO in the same dilution as that present in the KYNA-containing ACSF (i.e., 1:100,000), the average frequency of IPSCs recorded from 12 CA1 pyramidal neurons of three WT mice was $1.8 \pm 0.25 \mathrm{~Hz}$ (mean \pm SEM). Likewise, in hippocampal slices that were perfused for $1 \mathrm{hr}$ with KYNA (100 nM)-containing ACSF, the average frequency of IPSCs recorded from 10 CA1 pyramidal neurons of two other WT mice was $1.8 \pm 0.41 \mathrm{~Hz}$ (mean \pm SEM). In contrast, the cumulative distribution of interevent intervals of IPSCs recorded from CA1 pyramidal neurons of $m \mathrm{Kat}-2^{-/-}$mice was significantly altered by the in situ exposure to KYNA (Fig. 9F) When hippocampal slices from $m \mathrm{Kat}-2^{-/-}$mice were perfused with ACSF containing DMSO $(1: 100,000)$ or KYNA (100 nM), the average frequencies of IPSCs recorded from CA1 pyramidal neurons were $3.9 \pm 0.47 \mathrm{~Hz}$ (mean $\pm \mathrm{SEM} ; n=8$ neurons from two $m$ Kat $-2^{-1-}$ mice) and $2.9 \pm 0.29 \mathrm{~Hz}$ (mean $\pm \mathrm{SEM} ; n=8$ neurons from two $m$ Kat $-2^{-1-}$ mice), respectively. Thus, at $100 \mathrm{nM}$, KYNA reduced by $\sim 25 \%$ the frequency of IPSCs recorded from CA1 pyramidal neurons of $m$ Kat $-2^{-/-}$mice. Changes in the amplitude of IPSCs by in situ exposure of the $m$ Kat $-2^{-/-}$hippocampal slices to KYNA (100 nM) were very small (Fig. 9F). The average amplitudes of IPSCs recorded in the absence and in the presence of $100 \mathrm{~nm}$ KYNA were $12.6 \pm 0.21 \mathrm{pA}(n=12,260$ events) and $11.7 \pm 0.22 \mathrm{pA}(n=8536$ events $)$, respectively.

KYNA-induced reduction in the frequency of IPSCs recorded from CA1 pyramidal neurons of $m$ Kat $-2^{-/-}$mice was the result of its interaction with $\alpha 7^{\star}$ nAChRs because, after a 10 min perfusion of the hippocampal slices with ACSF-containing $\alpha$-BGT (100 nM), an additional $1 \mathrm{hr}$ incubation of the slices with ACSF containing KYNA (100 nM) plus $\alpha$-BGT (100 nM) caused no additional changes in the frequency of IPSCs. In hippocampal slices from $m$ Kat $-2^{-1-}$ mice, the frequency of IPSCs recorded in the presence of KYNA plus $\alpha$-BGT from 10 CA1 pyramidal neurons was $101.3 \pm 5.01 \%$ (mean $\pm \mathrm{SEM}$ ) of that recorded in the presence of $\alpha$-BGT alone from six CA1 pyramidal neurons.

\section{Correlation between dendritic length and $\alpha 7^{\star} \mathrm{nAChR}$ activity evoked by exogenous application of choline to CA1 SR interneurons in 21-d-old WT and $m \mathrm{Kat}_{-} 2^{-/-}$mice}

Previous studies have shown that $\alpha 7^{\star} \mathrm{nAChR}$ density increases along with dendritic length in hippocampal neurons in culture (Albuquerque et al., 1997; Zarei et al., 1999) and decreases along the dendrites of hippocampal CA1 interneurons in slices (Khiroug et al., 2003). To determine whether increased $\alpha 7^{\star} \mathrm{nAChR}$ activity in CA1 SR interneurons of $m \mathrm{Kat}-2^{-/-}$mice was accompanied by changes in dendritic length in these neurons, two approaches were taken. First, the Neurolucida software was used to 
A

WT

ACh, $0.1 \mathrm{mM}$

$m K a t-2^{-1-}$
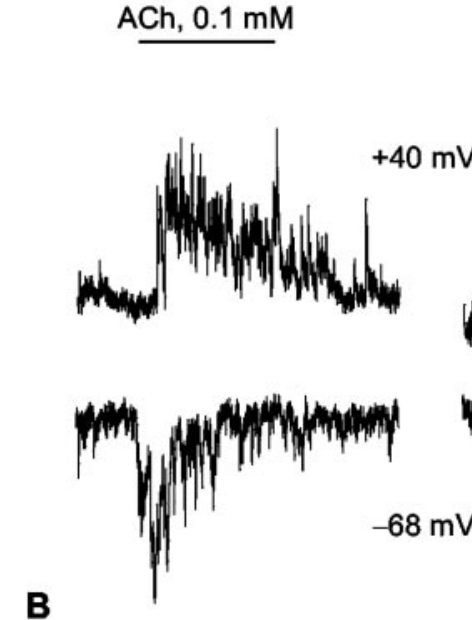

$-68 m V$
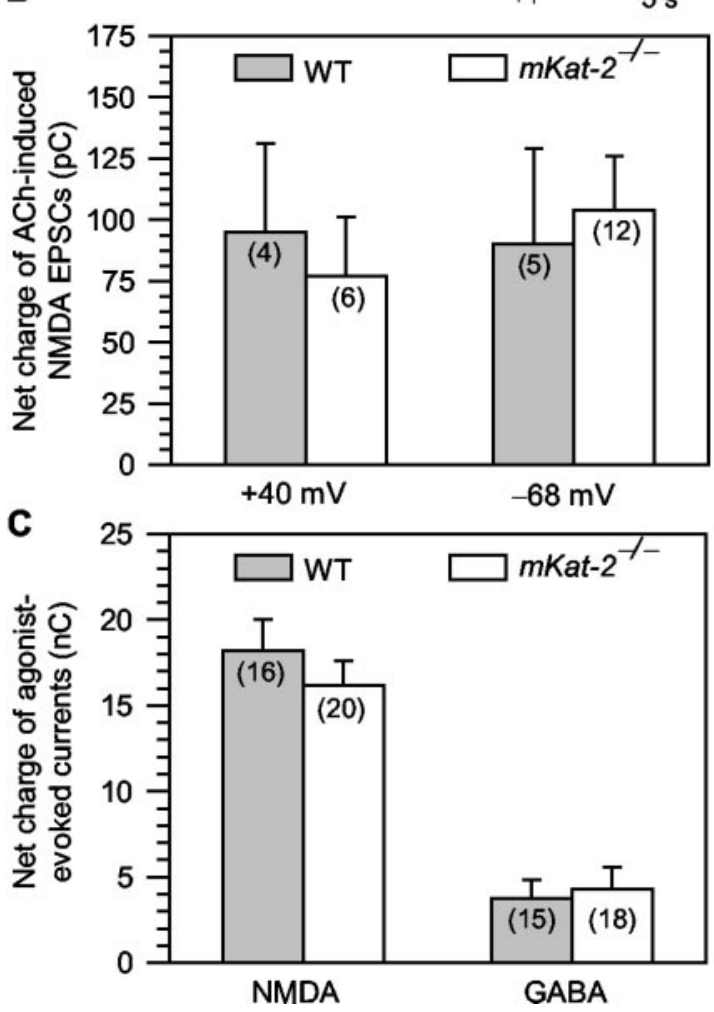

Figure 6. Quantification of $\alpha 3 \beta 4^{*}$ nAChR-mediated responses and NMDA plus glycine- or GABA-evoked whole-cell currents recorded from CA1 SR interneurons in hippocampal slices of 21-d-old WT and $m K a t-2^{-1-}$ mice. A, Sample recordings of ACh-evoked NMDA EPSCs obtained at +40 or $-68 \mathrm{mV}$ from CA1 SR interneurons of hippocampal slices from WT and $m K$ Kat- $2^{-1-}$ mice. ACSF contained atropine $(1 \mu \mathrm{M})$ and bicuculline $(10 \mu \mathrm{m})$. Responses at $+40 \mathrm{mV}$ were recorded using $\mathrm{Mg}^{2+}$-containing ACSF, whereas those at $-68 \mathrm{mV}$ were recorded using nominally $\mathrm{Mg}^{2+}$-free ACSF. B, Quantification of the net charge of ACh-evoked NMDA EPSCs at the different membrane potentials in both animal groups. Numbers of neurons studied are shown in parentheses. Graph and error bars are the mean and SEM, respectively, of results obtained from the various neurons. Results obtained from WT and $m K a t-2^{-1-}$ mice were not significantly different (unpaired Student's $t$ test). C, Quantitative analysis of the net charge carried by whole-cell currents evoked by GABA (20 $\mu \mathrm{M})$ or NMDA $(50 \mu \mathrm{m})$ plus glycine $(10 \mu \mathrm{M})$ in CA1 SR interneurons of hippocampal slices from WT and $m K a t-2^{-1-}$ mice. Membrane potential, -68 mV. NMDA-evoked currents were recorded using $\mathrm{Mg}^{2+}$-free ACSF; GABA-evoked currents were recorded in the presence of TTX ( $200 \mathrm{nM})$ and using a $\mathrm{Cs}(\mathrm{Cl}$-containing pipette solution. The net charge of agonist-evoked whole-cell currents was analyzed in both animal groups. Numbers of neurons studied are shown in parentheses. Graph and error bars are the mean and SEM, respectively, of results obtained from the various neurons. According to the unpaired Student's $t$ test, results obtained from WT and $m K K_{a t}-2^{-/-}$mice were not significantly different.
Table 2. Characteristics of AMPA EPSCs recorded from CA1 SR interneurons of mouse hippocampal slices

\begin{tabular}{lcc}
\hline & WT & mKat- $2^{-/-}$ \\
\hline Frequency (Hz) & $0.296 \pm 0.075$ & $0.225 \pm 0.044$ \\
Peak amplitude (pA) & $15.0 \pm 0.99$ & $15.0 \pm 0.87$ \\
Rise time (msec) & $0.94 \pm 0.10$ & $0.96 \pm 0.08$ \\
$\tau_{\text {decay }}$ (msec) & $3.53 \pm 0.29$ & $4.26 \pm 0.41$ \\
\hline
\end{tabular}

All experiments were performed using $\mathrm{Mg}^{2+}$-containing ACSF, and recordings were obtained from interneurons voltage clamped at $-68 \mathrm{mV}$. Data are presented as mean \pm SEM of results obtained from eight neurons of WT mice and 14 neurons of mKat- $^{-1-}$ mice.

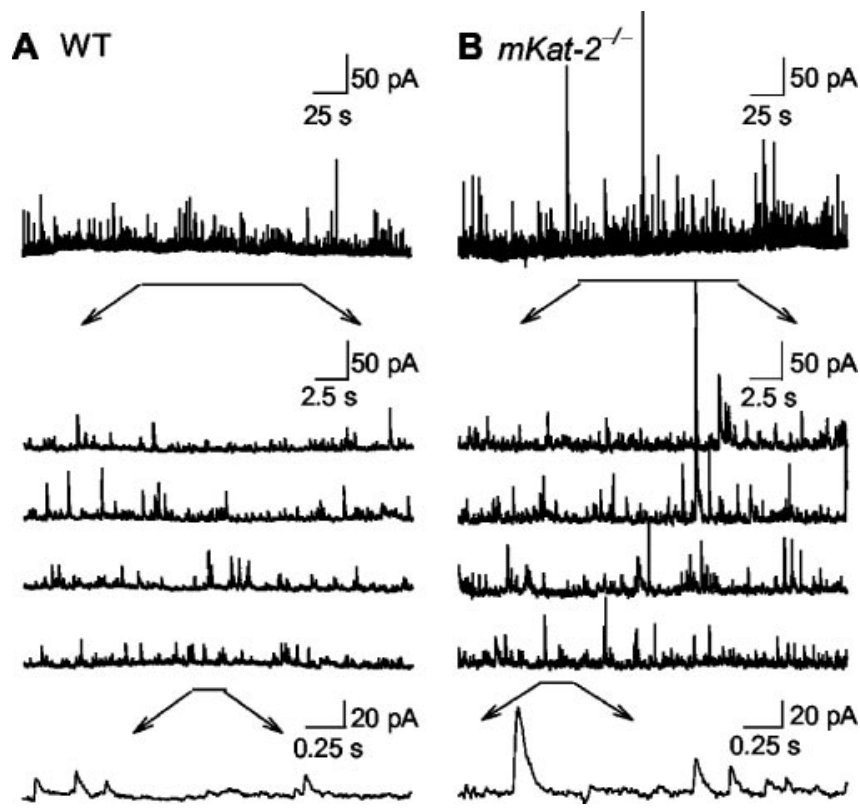

Figure 7. Representative sample recordings of spontaneously occurring IPSCs obtained from CA1 pyramidal neurons of 21-d-old WT and $m K K_{a t-2^{-1-}}$ mice. Top traces in $A$ and $B$ show continuous 5 min recordings of IPSCs obtained from CA1 pyramidal neurons voltage clamped at $0 \mathrm{mV}$ in hippocampal slices from a 21-d-old WT mouse $(A)$ and a 21-d-old $m K$ Kat-2 ${ }^{-1-}$ mouse. For better visualization of the individual IPSCS, middle and bottom traces in $A$ and $B$ show, at expanded time scales, episodes from the same recordings displayed on top. ACSF contained $1 \mathrm{~mm} \mathrm{Mg}^{2+}$, and the methanesulfonate-based internal solution was used to fill up the pipettes.

Table 3. Characteristics of IPSCs recorded from CA1 pyramidal neurons of mouse hippocampal slices

\begin{tabular}{lcc}
\hline & WT & mKat-2 \\
\hline$\tau_{\text {decay }}$ (msec) & $48.1 \pm 0.21$ & $49.2 \pm 0.13$ \\
Frequency $(\mathrm{Hz})$ & $1.9 \pm 0.27$ & $3.3 \pm 0.45^{*}$ \\
\hline
\end{tabular}

All experiments were performed using $\mathrm{Mg}^{2+}$-containing $\mathrm{ACSF}$, and recordings were obtained from CA1 pyramidal neurons voltage clamped at $0 \mathrm{mV}$. Values of frequency of events (number of IPSC recorded for $5 \mathrm{~min}$ divided by the recording time) and $\tau_{\text {decay }}$ are presented as mean \pm SEM of results obtained from 12 neurons of WT mice and 12 neurons of $m$ Kat- $2^{-/-}$mice.

${ }^{*} p<0.02$; unpaired Student's 5 test.

measure the dendritic length of CA1 SR interneurons from which recordings were obtained. Second, correlational analyses were performed to determine whether dendritic length was correlated with the magnitude of $\alpha 7^{\star} \mathrm{nAChR}$ activity induced by $\mathrm{U}$-tube application of choline to the interneurons.

After the electrophysiological recordings were obtained, reconstruction of the image of biocytin-filled interneurons revealed that the morphological features of the neurons studied in hippocampal slices of WT mice were very similar to those of the neurons studied in slices of $m \mathrm{Kat}-2^{-/-}$mice (Fig. 10A). All interneurons studied had their cell bodies located in the CA1 SR. 

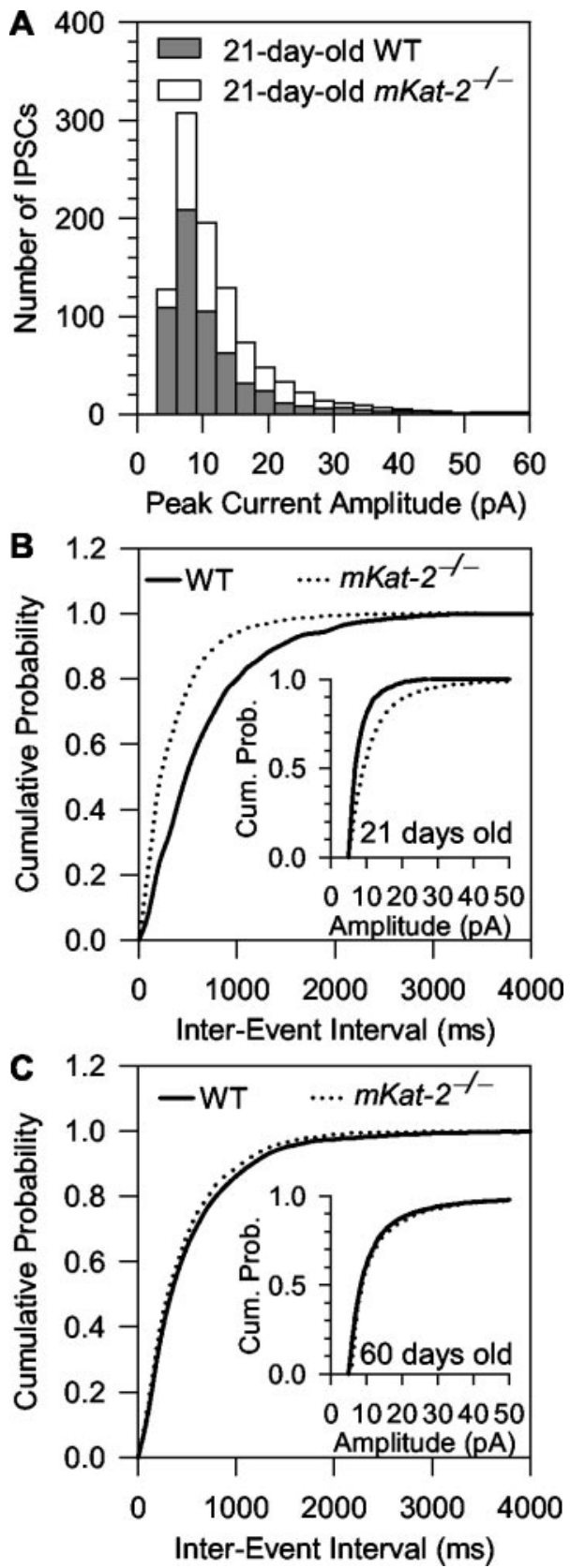

Figure 8. Analysis of spontaneously occurring IPSCs recorded from CA1 pyramidal neurons in hippocampal slices of WT and mKat- $2^{-/-}$at 21 or $60 \mathrm{~d}$ of age. A, Superimposed histogram distributions of peak amplitudes of IPSCs recorded from CA1 pyramidal neurons of 21-d-old WT and $\mathrm{mKat}-2^{-/-}$mice. IPSCs were recorded for $5 \mathrm{~min}$ from each neuron studied at $0 \mathrm{mV}$ using $\mathrm{Mg}^{2+}$-containing ACSF and Cs methanesulfonate-based internal solution. The bin width in the histograms is $3 \mathrm{pA}$. Results are the average of the histogram distributions obtained from seven neurons in hippocampal slices from four WT mice and six neurons in hippocampal slices from three $m$ Kat- $2^{-1-}$ mice. $B$, Cumulative probability plots of interevent intervals and peak amplitude (inset) of IPSCs recorded under the same conditions as those described in $A$ from CA1 pyramidal neurons in hippocampal slices of 21-d-old WT and $m K^{2} a t-2^{-1-}$ mice. Plots are averages of cumulative probability plots obtained from seven neurons in hippocampal slices from four WT mice and six neurons in hippocampal slices from three $m$ Kat $-2^{-1-}$ mice. Results obtained from $m K$ Kat- $2^{-1-}$ and WT mice were significantly different according to the $K-S$ test ( $p<0.001$ for differences in the cumulative plots of interevent intervals, and $p=0.002$ for cumulative plots of amplitudes). C, Cumulative probability plots of interevent intervals and peak amplitudes (inset) of IPSCs recorded under the same conditions as those described in $A$ from CA1 pyramidal neurons in hippocampal slices of 60-d-old WT and $m K a t-2^{-1-}$ mice. Plots are averages of cumulative probability plots obtained from nine neurons in hippocampal slices from four WT mice and eight neurons in hippocampal slices from four $m K a t-2^{-1-}$ mice. According to the $\mathrm{K}-\mathrm{S}$ test, results obtained from $m K \mathrm{Kat}_{-2}{ }^{-/-}$and WT mice were not significantly different.
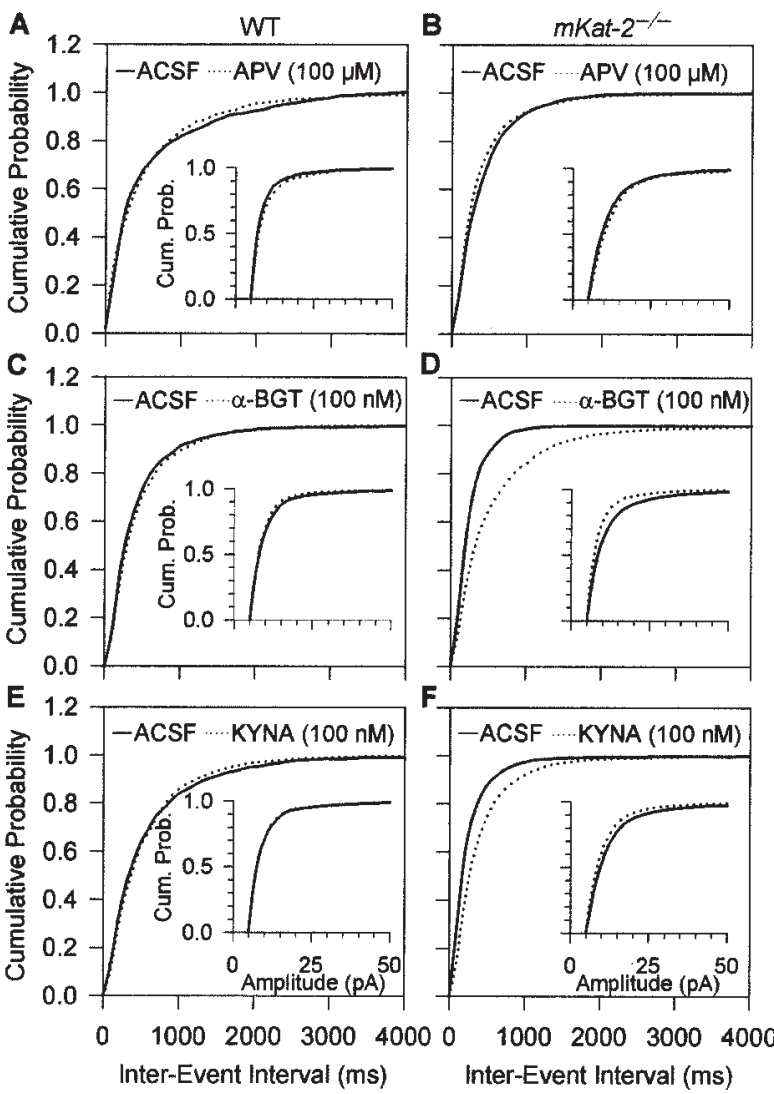

Figure 9. Effects of the NMDA receptor antagonist APV and of the $\alpha 7^{*} \mathrm{nAChR}$ antagonist $\alpha$-BGT on spontaneously occurring IPSCs recorded from CA1 pyramidal neurons in hippocampal slices of 21-d-old WT and $m K$ Kat- $2^{-1-}$ mice. $A, B$, Cumulative probability plots of interevent intervals and peak amplitudes of IPSCs recorded at $0 \mathrm{mV}$ from CA1 pyramidal neurons of WT mice $(A)$ or $m K$ Kat $-2^{-1-}$ mice for 5 min before and during 5 min exposure of the hippocampal slices to the NMDA receptor antagonist APV $(100 \mu \mathrm{M})$. Plots are averages of cumulative probability plots obtained from four neurons in hippocampal slices from three WT mice and four neurons in hippocampal slices from three $m K a t-2^{-1-}$ mice. According to the K-S test, APV did not affect the results obtained in each animal group. C, D, Cumulative probability plots of interevent intervals and peak amplitudes of IPSCs recorded at $0 \mathrm{mV}$ from CA1 pyramidal neurons of WT mice $\left(C\right.$ or $m$ Kat $-2^{-/}$mice $(D)$ for 5 min before and for 5 min after a 10 min perfusion of the hippocampal slices with ACSF containing $\alpha$-BGT (100 nM). Plots are averages of cumulative probability plots obtained from six neurons in hippocampal slices from four WT mice and seven neurons in hippocampal slices from three $m K a t-2^{-1-}$ mice. According to the $\mathrm{K}-\mathrm{S}$ test, the results obtained from WT neurons in the absence and in the presence of $\alpha$-BGT did not differ significantly. However, the results obtained from mKat-2 $2^{-1-}$ neurons in the presence of $\alpha$-BGT were significantly different from those obtained in the absence of the toxin $(p<0.001$ for differences in both cumulative plots). $E$, $F$, Cumulative probability plots of interevent intervals and peak amplitudes of IPSCs recorded at $0 \mathrm{mV}$ from CA1 pyramidal neurons of WT mice $(E)$ or $m$ Kat $-2^{-1-}$ mice $(F)$ under control conditions (ACSF) or $1 \mathrm{hr}$ after exposure of the hippocampal slices to ACSF containing KYNA $(100 \mathrm{~nm})$. Graphs are averages of cumulative probability plots obtained from six neurons in hippocampal slices from four WT mice and seven neurons in hippocampal slices from three $m K a t-2^{-/-}$mice. According to the K-S test, the results obtained from WT neurons in the absence and in the presence of KYNA did not differ significantly. However, the cumulative plots of interevent intervals obtained from $m$ Kat- $2^{-1-}$ neurons in the presence of KYNA were significantly different from those obtained in the absence of the metabolite $(p<0.05)$. KYNA also caused a small left shift that came close to the level of significance ( $p=0.06$ according to the K-S test) in the cumulative plot of amplitudes of IPSCS recorded from the mutant neurons.

Although the axons of all successfully labeled interneurons branched mostly within the CA1 SR, some projected into the stratum oriens $(n=12$ of 24 neurons in WT mice and 6 of 20 neurons in $m \mathrm{Kat}-2^{-1-}$ mice) and others projected into the stratum lacunosum-moleculare $(n=12$ of 24 neurons in WT and 14 of 20 neurons in $m \mathrm{Kat}-2^{-/-}$mice). In contrast, the dendrites of 
A

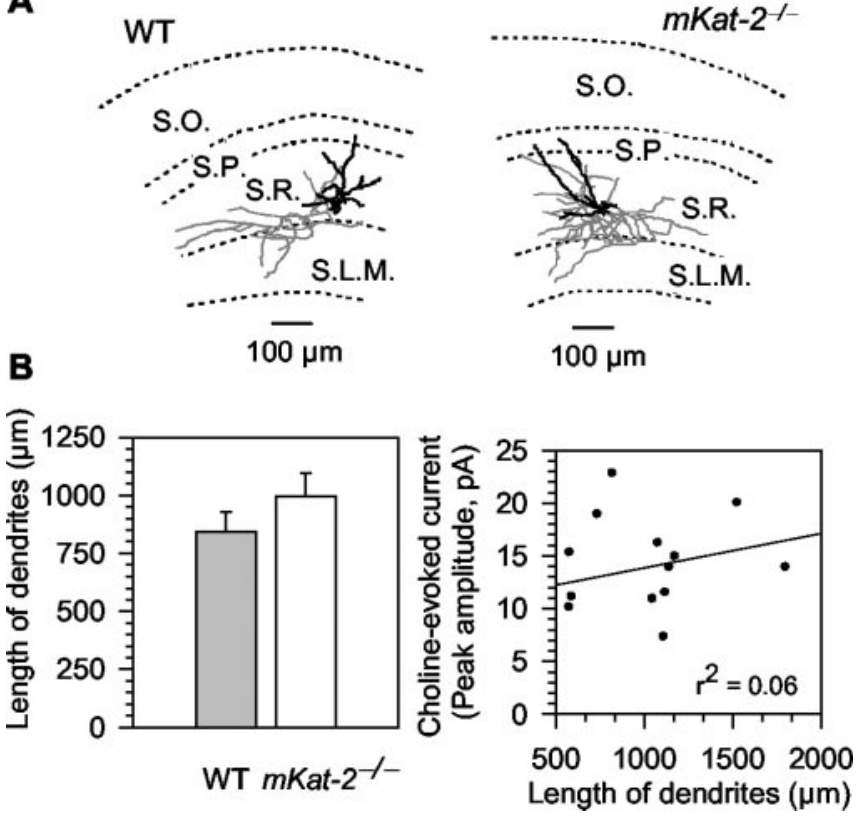

Figure 10. Morphological analysis of CA1 SR interneurons from which recordings were obtained and correlational analysis of dendritic length and amplitude of choline-evoked wholecell currents. $A$, Neurolucida drawings of biocytin-filled CA1 SR interneurons studied electrophysiologically in hippocampal slices of 21-d-old WT and $m K_{\text {Kat- }} 2^{-/-}$mice. One representative sample of each animal group is shown. Dendrites are represented as thick black lines, and axons are represented as thin gray lines. $B$, Quantitative analysis of the dendritic length of CA1 SR interneurons of WT and $m$ Kat $-2^{-1-}$ mice. Graph and error bars are the mean and SEM, respectively, of results obtained from 11 neurons of WT mice and 13 neurons of $m$ Kat- $2^{-1-}$ mice. C, Analysis of correlation between the amplitude of choline-evoked whole-cell currents and the dendritic length of that neuron. The straight line represents the linear regression of the points, and $r^{2}$ is the regression coefficient.

the CA1 SR interneurons studied in hippocampal slices of WT and $m$ Kat $-2^{-/-}$mice were confined primarily to the CA1 SR (Fig. $10 A)$. No significant differences were observed between the length of dendrites of CA1 SR interneurons of 21-d-old WT and mKat $-2^{-1-}$ mice (Fig. 10A,B), and the amplitudes of cholineevoked whole-cell currents recorded from these interneurons showed no correlation with dendritic length (Fig. 10C). Therefore, it can be concluded that the increased $\alpha 7^{*}$ nAChR activity detected in CA1 SR interneurons of $m \mathrm{Kat}_{-2^{-/-}}$mice neither depend on nor caused significant changes in the dendritic length of these neurons.

\section{Discussion}

In this study, the use of $m \mathrm{Kat}_{-2^{-/-}}$mice revealed that physiological levels of the tryptophan metabolite KYNA, although insufficient to modulate NMDA receptor activity, are sufficient to lower $\alpha 7^{\star}$ nAChR activity in CA1 SR interneurons and, consequently, to attenuate GABAergic synaptic activity impinging onto CA1 pyramidal neurons in the hippocampus.

The present findings challenge the assumption that the biological effects of KYNA result exclusively from its action as a competitive antagonist of glycine at NMDA receptors (Stone, 1993; Danysz and Parsons, 1998; Schwarcz and Pellicciari, 2002). This mechanism of action for KYNA, which was originally proposed in the late 1980s (Mayer et al., 1988) (for review, see Danysz and Parsons, 1998), has been indirectly supported by evidence that the glycine site of NMDA receptors is not saturated in vivo (Salt, 1989; Thomson et al., 1989; Bergeron et al., 1998; Kinney et al., 2003) and that, in the nominal absence of glycine, KYNA blocks NMDA receptors with an $\mathrm{IC}_{50}$ of $\sim 15 \mu \mathrm{M}$ (Henderson et al., 1990; Parsons et al., 1997; Hilmas et al., 2001). However, the apparent potency for KYNA to block NMDA receptors decreases sharply with increasing glycine concentrations. In the presence of glycine concentrations similar to those found extracellularly in the CNS (i.e., 5-10 $\mu \mathrm{M}$ ) (Kennedy et al., 2002), KYNA blocks NMDA receptors with an $\mathrm{IC}_{50}$ of $\sim 250 \mu \mathrm{M}$. This concentration is unlikely to be reached in the brain in vivo (Scharfman et al., 1999; Frankiewicz et al., 2000; Urenjak and Obrenovitch, 2000; Hilmas et al., 2001).

\section{$\alpha 7^{\star}$ nAChRs are major targets for the actions of KYNA in} the brain

As observed in the rat hippocampus (Alkondon and Albuquerque, 2001; Adams et al., 2002), in the mouse hippocampus, the majority of CA1 SR interneurons ( $>80 \%$ of the sampled interneurons) express somatodendritic $\alpha 7^{\star} \mathrm{nAChRs}$, and $\alpha 7^{\star} \mathrm{nAChR}$ expression reaches adult levels by the third postnatal week. However, in CA1 SR interneurons of 21-d-old WT mice, the amplitudes of $\alpha 7^{\star}$ nAChR-mediated whole-cell currents are considerably smaller than those recorded from CA1 SR interneurons in hippocampal slices of age-matched rats (Alkondon et al., 1999). This could be explained by differences in the number of surface $\alpha 7^{\star}$ nAChRs in hippocampal interneurons between the two species. In fact, such differences have been reported even among different mouse strains (Marks et al., 1996; Gahring et al., 2004).

Analysis of amplitude and net charge of choline-evoked currents indicated that $\alpha 7^{\star}$ nAChR activity in CA1 SR interneurons was $\sim 65 \%$ higher in 21 -d-old $m \mathrm{Kat}_{-} 2^{-/-}$mice than in agematched WT mice. Binding studies performed in membrane hippocampal preparations suggested that this increased $\alpha 7^{\star} \mathrm{nAChR}$ activity may not have resulted from changes in numbers of surface $\alpha 7^{\star}$ nAChRs. Although an indirect effect cannot be completely ruled out, the increased $\alpha 7^{\star}$ nAChR activity in the interneurons of $m \mathrm{Kat}_{-2^{-1-}}$ mice can be accounted for solely by a reduction in nAChR blockade by endogenous KYNA (Hilmas et al., 2001).

The effect of the targeted mutation appeared to be quite specific for $\alpha 7^{\star}$ nAChRs. Decreased hippocampal KYNA levels in 21-d-old $m \mathrm{Kat}^{-2^{-1-}}$ mice did not lead to significant changes in NMDA receptor activity in the CA1 SR interneurons, as indicated by measurements of whole-cell currents evoked by exogenously applied NMDA. In addition, ongoing endogenous NMDA receptor activity had no detectable contribution to regulation of GABAergic synaptic activity impinging onto CA1 pyramidal neurons of both WT and mutant mice.

In the mouse hippocampus, like in the rat hippocampus (Alkondon et al., 2003a), stimulation of $\alpha 3 \beta 4^{\star}$ nAChRs in glutamatergic neurons enhanced glutamatergic input to CA1 SR interneurons. The activity of postsynaptic AMPA receptors on CA1 SR interneurons, the spontaneous release of glutamate onto the interneurons, and the activity of presynaptically located $\alpha 3 \beta 4^{*}$ nAChRs were not altered by the lower hippocampal levels of KYNA resulting from the targeted deletion of the $m$ Kat-2 gene. Endogenous levels of KYNA were also insufficient to modulate $\alpha 4 \beta 2^{*}$ nAChR expression in the hippocampus. Although prolonged in vitro exposure of hippocampal neurons to $10 \mu \mathrm{M}$ KYNA causes upregulation of functional $\alpha 4 \beta 2^{\star}$ nAChRs (Hilmas et 
al.,2001; Pereira et al., 2002), the number of $\left[{ }^{3} \mathrm{H}\right]$ epibatidine binding sites in hippocampal membranes of 21-d-old WT and mutant mice were comparable (Table 1). Therefore, endogenous levels of KYNA in the hippocampus selectively modulate $\alpha 7^{\star}$ nAChR activity.

\section{GABAergic synaptic transmission is selectively increased in the hippocampus of 21-d-old $m K a t-2^{-/}$mice: relationship with higher $\alpha 7^{\star} \mathrm{nAChR}$ activity in CA1 interneurons, lower hippocampal levels of KYNA, and increased locomotor activity}

In the mouse and rat hippocampus, GABA release is regulated by $\alpha 7^{\star}$ nAChRs (Alkondon and Albuquerque, 2001; Dobelis et al., 2003). In the rat hippocampus, agonist-induced activation of $\alpha 7^{\star}$ nAChRs in CA1 SR interneurons, which are known to synapse onto proximal dendrites of CA1 pyramidal neurons (Gulyás and Freund, 1996; Oliva et al., 2000; Buzaski et al., 2003), enhances GABAergic synaptic activity impinging onto the pyramidal neurons (Alkondon and Albuquerque, 2001). Thus, it can be hypothesized that a higher endogenous activity of $\alpha 7^{\star}$ nAChRs in CA1 interneurons accounts for the increased GABAergic activity impinging onto the CA1 pyramidal neurons of the 21-d-old $m$ Kat $-2^{-1-}$ mice. This hypothesis is supported by the finding that the $\alpha 7 \mathrm{nAChR}$ antagonist $\alpha$-BGT brought the IPSC frequency and amplitude recorded from CA1 pyramidal neurons of 21-dold $m$ Kat $-2^{-/-}$mice to values similar to those recorded from age-matched WT mice. Our hypothesis would also predict that adding a background level of KYNA to the hippocampal slices of $m K a t-2^{-1-}$ mice should reduce the endogenous activity of $\alpha 7^{\star}$ nAChRs in the interneurons and, consequently, decrease the GABAergic activity impinging onto the pyramidal neurons. In fact, in vitro exposure of hippocampal slices from $m \mathrm{Kat}-2^{-1-}$ mice to $100 \mathrm{nM}$ KYNA significantly decreased the frequency of IPSCs recorded from CA1 pyramidal neurons, and this effect could not be observed after blockade of the $\alpha 7^{\star}$ nAChRs by $\alpha$-BGT.

In 21-d-old $m k a t-2^{-/-}$mice, the reduction of hippocampal KYNA levels was accompanied by a readily observable phenotype, i.e., enhanced spontaneous locomotor activity, which can be a result of the increased GABAergic activity in the hippocampus. There are reports that locomotor activity increases in DBA2 mice and rats after intrahippocampal microinjection of the $\mathrm{GABA}_{\mathrm{A}}$ receptor agonist muscimol, the GABA degradation inhibitor $\gamma$-vinyl-GABA, or GABA itself (van Abeelen and Boersma, 1984; Alvarez and Banzan, 1990). At 60 d of age, hippocampal KYNA levels and locomotor activity of $m$ Kat-2 $2^{-\prime-}$ mice converged to values comparable with those measured in WT mice. Thus, it is plausible to hypothesize that, as KYNA levels increase in the hippocampus of the 60 -d-old mice, $\alpha 7^{\star} \mathrm{nAChR}$ activity in the CA1 SR interneurons decreases and consequently reduces the GABAergic transmission between these neurons and the pyramidal neurons.

\section{Interactive signaling between glial cells and neurons is crucial for proper functioning of the hippocampus}

Numerous studies have suggested that a network of interactive neurons and glial cells controls brain function (Boehning and Snyder, 2003). Astrocytes, which frequently engulf synapses with their processes and release a host of neuroactive compounds, are important players in the governance of these interactions, especially as they relate to excitatory neurotransmission (Bezzi et al.,
2001). For example, astrocytes produce and release the amino acid D-serine, which increases NMDA receptor activity in neurons by acting as an agonist at the glycine site of these receptors (Snyder and Kim, 2000). Similarly, the enzyme glutamate carboxypeptidase II is expressed on the cytoplasmic membrane of astrocytes and influences neuronal glutamatergic activity by hydrolyzing the neuropeptide $N$-acetylaspartylglutamate, which is primarily stored in and released from CNS glutamatergic and cholinergic terminals (Wroblewska et al., 1993; Coyle, 1997).

The present demonstration that reduction of physiological levels of KYNA, which is preferentially produced by and released from astrocytes in the brain (Roberts et al., 1992; Guillemin et al., 2000, 2001; Kiss et al., 2003), is associated with a specific phenotype and regulates $\alpha 7^{\star} \mathrm{nAChR}$ activity in interneurons as well as synaptic transmission between these neurons and pyramidal cells in the hippocampus lends support to the concept that glial neuronal signaling is essential for proper brain functioning. In particular, KYNA released by astrocytes closely apposed to GABAergic axons synapsing onto pyramidal neurons would interact with $\alpha 7^{\star}$ nAChRs in the GABAergic axons. Regulation by endogenous KYNA of the $\alpha 7^{\star}$ nAChR activity in the GABAergic axons could then determine the level of GABAergic synaptic activity impinging onto the pyramidal neurons and, indirectly, regulate the excitability of these neurons. The interplay between glia-derived KYNA and the nicotinic cholinergic system could be essential in the pathogenesis of numerous catastrophic brain disorders, including schizophrenia and Alzheimer's disease, in which brain KYNA levels are elevated, and nicotinic and GABAergic functions are impaired (Tamminga, 1998; Baran et al., 1999; Court et al., 1999; Bartus, 2000; Schwarcz et al., 2001).

\section{References}

Adams CE, Broide RS, Chen Y, Winzer-Serhan UH, Henderson TA, Leslie FM, Freedman R (2002) Development of the alpha7 nicotinic cholinergic receptor in rat hippocampal formation. Brain Res Dev Brain Res 139:175-187.

Albuquerque EX, Alkondon M, Pereira EFR, Castro NG, Schrattenholz A, Barbosa CTF, Bonfante-Cabarcas R, Aracava Y, Eisenberg HM, Maelicke A (1997) Properties of neuronal nicotinic acetylcholine receptors: pharmacological characterization and modulation of synaptic function. J Pharmacol Exp Ther 280:1117-1136.

Alkondon M, Albuquerque EX (2001) Nicotinic acetylcholine receptor alpha7 and alpha4beta2 subtypes differentially control GABAergic input to CA1 neurons in rat hippocampus. J Neurophysiol 86:3043-3055.

Alkondon M, Albuquerque EX (2002) A non-alpha7 nicotinic acetylcholine receptor modulates excitatory input to hippocampal CA1 interneurons. J Neurophysiol 87:1651-1654.

Alkondon M, Pereira EFR, Eisenberg HM, Albuquerque EX (1999) Choline and selective antagonists identify two subtypes of nicotinic acetylcholine receptors that modulate GABA release from CA1 interneurons in rat hippocampal slices. J Neurosci 19:2693-2705.

Alkondon M, Pereira EFR, Albuquerque EX (2003a) NMDA and AMPA receptors contribute to the nicotinic cholinergic excitation of CA1 interneurons in the rat hippocampus. J Neurophysiol 90:1613-1625.

Alkondon M, Pereira EFR, Fawcett WP, Randall WR, Guidetti P, Sapko MT, Tagle DA, Schwarcz R, Albuquerque EX (2003b) Endogenous kynurenic acid regulates $\alpha 7$ nicotinic receptor activity in the hippocampus. Soc Neurosci Abstr 29:248.9.

Alvarez EO, Banzan AM (1990) Behavioral effects of GABA in the hippocampal formation: functional interaction with histamine. Behav Brain Res 37:133-143.

Arancio O, Korn H, Gulyás A, Freund T, Miles R (1994) Excitatory synapticconnections onto rat hippocampal inhibitory cells may involve a single transmitter release site. J Physiol (Lond) 481:395-405. 
Baran H, Jellinger K, Deecke L (1999) Kynurenine metabolism in Alzheimer's disease. J Neural Transm 106:165-181.

Bartus RT (2000) On neurodegenerative diseases, models, and treatment strategies: lessons learned and lessons forgotten a generation following the cholinergic hypothesis. Exp Neurol 163:495-529.

Bergeron R, Meyer TM, Coyle JT, Greene RW (1998) Modulation of $\mathrm{N}$-methyl-D-aspartate receptor function by glycine transport. Proc Natl Acad Sci USA 22:15730-15734.

Bezzi P, Domercq M, Vesce S, Volterra A (2001) Neuron-astrocyte crosstalk during synaptic transmission: physiological and neuropathological implications. Prog Brain Res 132:255-265.

Boehning D, Snyder SH (2003) Novel neural modulators. Annu Rev Neurosci 26:105-131.

Buzaski G, Buhl DL, Harris KD, Csicsvari J, Czeh B, Morozov A (2003) Hippocampal network patterns of activity in the mouse. Neuroscience 116:201-211.

Court J, Spurden D, Lloyd S, McKeith I, Ballard C, Cairns N, Kerwin R, Perry R, Perry E (1999) Neuronal nicotinic receptors in dementia with Lewy bodies and schizophrenia: alpha-bungarotoxin and nicotine binding in the thalamus. J Neurochem 73:1590-1597.

Coyle JT (1997) The nagging question of the function of $\mathrm{N}$-acetylaspartylglutamate. Neurobiol Dis 4:231-238.

Danysz W, Parsons CG (1998) Glycine and N-methyl-D-aspartate receptors: physiological significance and possible therapeutic applications. Pharmacol Rev 50:597-664.

Dobelis P, Hutton S, Lu Y, Collins AC (2003) GABAergic systems modulate nicotinic receptor-mediated seizures in mice. J Pharmacol Exp Ther 306:1159-1166.

Frankiewicz T, Pilc A, Parsons CG (2000) Differential effects of NMDAreceptor antagonists on long-term potentiation and hypoxic/hypoglycaemic excitotoxicity in hippocampal slices. Neuropharmacology 39:631-642.

Gahring LC, Persiyanov K, Dunn D, Weiss R, Meyer EL, Rogers SW (2004) Mouse strain-specific nicotinic acetylcholine receptor expression by inhibitory interneurons and astrocytes in the dorsal hippocampus. J Comp Neurol 468:334-346.

Guidetti P, Okuno E, Schwarcz R (1997) Characterization of rat brain kynurenine aminotransferases I and II. J Neurosci Res 50:457-465.

Guillemin GJ, Smith DG, Kerr SJ, Smythe GA, Kapoor V, Armati PJ, Brew BJ (2000) Characterisation of kynurenine pathway metabolism in human astrocytes and implications in neuropathogenesis. Redox Rep 5:108-111.

Guillemin GJ, Kerr SJ, Smythe GA, Smith DG, Kapoor V, Armati PJ, Croitoru J, Brew BJ (2001) Kynurenine pathway metabolism in human astrocytes: a paradox for neuronal protection. J Neurochem 78:842-853.

Gulyás AI, Freund TF (1996) Pyramidal cell dendrites are the primary targets of calbindin $\mathrm{D}_{28 \mathrm{k}}$-immunoreactive interneurons in the hippocampus. Hippocampus 6:525-534.

Hamill OP, Marty A, Neher E, Sakmann B, Sigworth FJ (1981) Improved patch-clamp techniques for high-resolution current recording from cells and cell-free membrane patches. Pflügers Arch 391:85-100.

Henderson G, Johnson JW, Ascher P (1990) Competitive antagonists and partial agonists at the glycine modulatory site of the mouse $\mathrm{N}$-methyl-Daspartate receptor. J Physiol (Lond) 430:189-212.

Hilmas C, Pereira EFR, Alkondon M, Rassoulpour A, Schwarcz R, Albuquerque EX (2001) The brain metabolite kynurenic acid inhibits $\alpha 7$ nicotinic receptor activity and increases non- $\alpha 7$ nicotinic receptor expression: physiopathological implications. J Neurosci 21:7463-7473.

Kennedy RT, Thompson JE, Vickroy TW (2002) In vivo monitoring of amino acids by direct sampling of brain extracellular fluid at ultralow flow rates and capillary electrophoresis. J Neurosci Methods 114:39-49.

Khiroug L, Giniatullin R, Klein RC, Fayuk D, Yakel JL (2003) Functional mapping and $\mathrm{Ca}^{2+}$ regulation of nicotinic acetylcholine receptor channels in rat hippocampal CA1 neurons. J Neurosci 23:9024-9031.

Kinney GG, Sur C, Burno M, Mallorga PJ, Williams JB, Figueroa DJ, Wittmann M, Lemaire W, Conn PJ (2003) The glycine transporter type 1 inhibitor $N$-[3-(4'-fluorophenyl)-3-(4'-phenylphenoxy)propyl] sarcosine potentiates NMDA receptor-mediated responses in vivo and produces an antipsychotic profile in rodent behavior. J Neurosci 23:7586-7591.
Kiss C, Ceresoli-Borroni G, Guidetti P, Zielke CL, Zielke HR, Schwarcz R (2003) Kynurenate production by cultured human astrocytes. J Neural Transm 110:1-14.

Lukas RJ, Changeux JP, Le Novere N, Albuquerque EX, Balfour DJ, Berg DK, Bertrand D, Chiappinelli VA, Clarke PB, Collins AC, Dani JA, Grady SR, Kellar KJ, Lindstrom JM, Marks MJ, Quik M, Taylor PW, Wonnacott S (1999) International Union of Pharmacology. XX. Current status of the nomenclature for nicotinic acetylcholine receptors and their subunits. Pharmacol Rev 51:397-401.

Marks MJ, Pauly JR, Grun EU, Collins AC (1996) ST/b and DBA/2 mice differ in brain $\alpha$-bungarotoxin binding and $\alpha 7$ nicotinic receptor subunit mRNA levels: a quantitative autoradiographic analysis. Brain Res Mol Brain Res 39:207-222.

Mayer ML, Westbrook GL, Vyklicky Jr L (1988) Sites of antagonist action on $\mathrm{N}$-methyl-D-aspartic acid receptors studied using fluctuation analysis and a rapid perfusion technique. J Neurophysiol 60:645-663.

McGehee DS (2002) Nicotinic receptors and hippocampal synaptic plasticity. it's all in the timing. Trends Neurosci 25:171-172.

Moroni F, Russi P, Lombardi G, Beni M, Carla V (1988) Presence of kynurenic acid in the mammalian brain. J Neurochem 51:177-180.

Naritsin DB, Boni RL, Markey SP (1995) Pentafluorobenzylation method for quantification of acidic tryptophan metabolites using electron capture negative ion mass spectrometry. Anal Chem 67:863-870.

Okuno E, Tsujimoto M, Nakamura M, Kido R (1993) 2-Aminoadipate-2oxoglutarate aminotransferase isoenzymes in human liver: a plausible physiological role in lysine and tryptophan metabolism. Enzyme Protein 47:136-148.

Oliva Jr AA, Jiang M, Lam T, Smith KL, Swann JW (2000) Novel hippocampal interneuronal subtypes identified using transgenic mice that express green fluorescent protein in GABAergic interneurons. J Neurosci 20:3354-3368.

Papke RL, Sanberg PR, Shytle RD (2001) Analysis of mecamylamine stereoisomers on human nicotinic receptor subtypes. J Pharmacol Exp Ther 297:646-656.

Parsons CG, Danysz W, Quack G, Hartmann S, Lorenz B, Wollenburg C, Baran L, Przegalinski E, Kostowski W, Krzascik P, Chizh B, Headley PM (1997) Novel systemically active antagonists of the glycine site of the $\mathrm{N}$-methyl-D-aspartate receptor: electrophysiological, biochemical and behavioral characterization. J Pharmacol Exp Ther 283:1264-1275.

Pereira EFR, Hilmas C, Santos MD, Alkondon M, Maelicke A, Albuquerque EX (2002) Unconventional ligands and modulators of nicotinic receptors. J Neurobiol 53:479-500.

Reddy PH, Charles V, Williams M, Miller G, Whetsell Jr WO, Tagle DA (1999) Transgenic mice expressing mutated full-length HD cDNA: a paradigm for locomotor changes and selective neuronal loss in Huntington's disease. Philos Trans R Soc Lond B Biol Sci 354:1035-1045.

Roberts RC, Du F, McCarthy KE, Okuno E, Schwarcz R (1992) Immunocytochemical localization of kynurenine aminotransferase in the rat striatum: a light and electron microscopic study. J Comp Neurol 326:82-90.

Salt TE (1989) Modulation of NMDA receptor-mediated responses by glycine and D-serine in the rat thalamus in vivo. Brain Res 481:403-406.

Scharfman HE, Hodgkins PS, Lee SC, Schwarcz R (1999) Quantitative differences in the effects of de novo produced and exogenous kynurenic acid in rat brain slices. Neurosci Lett 274:111-114.

Schwarcz R, Pellicciari R (2002) Manipulation of brain kynurenines: glial targets, neuronal effects, and clinical opportunities. J Pharmacol Exp Ther 303:1-10.

Schwarcz R, Rassoulpour A, Wu HQ, Medoff D, Tamminga CA, Roberts RC (2001) Increased cortical kynurenate content in schizophrenia. Biol Psychiatry 50:521-530.

Snyder SH, Kim PM (2000) D-amino acids as putative neurotransmitters: focus on D-serine. Neurochem Res 25:553-560.

Stone TW (1993) Neuropharmacology of quinolinic and kynurenic acid. Pharmacol Rev 45:309-379.

Stone TW (2001) Kynurenic acid antagonists and kynurenine pathway inhibitors. Expert Opin Investig Drugs 10:633-645.

Tamminga CA (1998) Schizophrenia and glutamatergic transmission. Crit Rev Neurobiol 12:21-36.

Thomson AM, Walker VE, Flynn DM (1989) Glycine enhances NMDA-- 
receptor mediated synaptic potentials in neocortical slices. Nature 338:422-424.

Turski WA, Nakamura M, Todd WP, Carpenter BK, Whetsell Jr WO, Schwarcz R (1988) Identification and quantification of kynurenic acid in human brain tissue. Brain Res 454:164-169.

Urenjak J, Obrenovitch TP (2000) Kynurenine 3-hydroxylase inhibition in rats: effects on extracellular kynurenic acid concentration and $\mathrm{N}$-methylD-aspartate-induced depolarisation in the striatum. J Neurochem 75:2427-2433.

van Abeelen JH, Boersma HJ (1984) A genetically controlled hippocampal transmitter system regulating exploratory behavior in mice. J Neurogenet $1: 153-158$.

Wroblewska B, Wroblewski JT, Saab OH, Neale JH (1993) N-acetylaspartyl- glutamate inhibits forskolin-stimulated cyclic AMP levels via a metabotropic glutamate receptor in cultured cerebellar granule cells. J Neurochem 61:943-948.

Yu P, Chen A, Schwarcz R, Tagle DA (1999a) Disruption of mouse kynurenine aminotransferase II gene, a possible factor in the pathophysiology of Huntington's disease. Am J Hum Genet 65:A500.

Yu P, Mosbrook DM, Tagle DA (1999b) Genomic organization and expression analysis of mouse kynurenine aminotransferase II, a possible factor in the pathophysiology of Huntington's disease. Mamm Genome 10:845-852.

Zarei MM, Radcliffe KA, Chen D, Patrick JW, Dani JA (1999) Distributions of nicotinic acetylcholine receptor alpha7 and beta2 subunits on cultured hippocampal neurons. Neuroscience 88:755-764. 